\title{
Negative pressure irrigation increases vegetable water productivity and nitrogen use efficiency by improving soil water and $\mathrm{NO}_{3}^{-}-\mathrm{N}$ distributions
}

\author{
Shengping $\mathrm{Li}^{\mathrm{a}}{ }^{\mathrm{b}}$, Deshui Tan ${ }^{\mathrm{c}}$, Xueping $\mathrm{Wu}^{\mathrm{a}}{ }^{\text {, }}$, Aurore Degré ${ }^{\mathrm{b}}$, Huaiyu Long ${ }^{\mathrm{a}, *}$, \\ Shuxiang Zhang ${ }^{\mathrm{a}}$, Jinjing Lu ${ }^{\mathrm{a}, \mathrm{b}}$, Lili Gao ${ }^{\mathrm{d}}$, Fengjun Zheng ${ }^{\mathrm{a}}$, Xiaotong Liu ${ }^{\mathrm{a}}$, Guopeng Liang ${ }^{\mathrm{e}}$ \\ ${ }^{\text {a }}$ Institute of Agricultural Resources and Regional Planning, Chinese Academy of Agricultural Sciences, Beijing 100081, PR China \\ ${ }^{\mathrm{b}}$ University de Liège, GxABT, Terra Research Center, 2 Passage des Déportés, Gembloux 5030, Belgium \\ ${ }^{\mathrm{c}}$ Institute of Agricultural Resources and Environment, Shandong Academy of Agricultural Sciences, Jinnan 250000, PR China \\ ${ }^{\mathrm{d}}$ Institute of Environment and Sustainable Development in Agriculture, Chianese Academy of Agricultural Sciences, Beijing 100081, PR China \\ ${ }^{\mathrm{e}}$ Department of Biology, Utah State University, Logan, Utah 84322, USA
}

\section{A R T I C L E I N F O}

Handling Editor-Dr R Thompson

\section{Keywords:}

Irrigation technique

Yield

Tomato and cucumber

Greenhouse

Soil water and nitrogen contents

\begin{abstract}
A B S T R A C T
Negative pressure irrigation (NPI), which is a new subsurface irrigation technique, promotes vegetable yield, water productivity (WP), and nitrogen use efficiency (NUE). However, it is not clear how NPI improves vegetable growth, especially in terms of water supply characteristics and uniformities of soil water and nitrogen. In this study, a cucumber pot experiment that had $0 \mathrm{kPa}$ (PW1), $-5 \mathrm{kPa}$ (PW2), -10 kPa (PW3), -15kPa (PW4), and traditional irrigation (PCK) treatments under nitrogen application (N1) and no application (N0) was conducted to reveal the water supply characteristics of NPI and its effect on vegetable growth. There are two main water supply characteristics: 1) automatically supplying irrigation water based on the consumption of soil water, and 2) keeping soil water content stable during the vegetable growth period. In addition, the relationship between vegetable growth and soil water and $\mathrm{NO}_{3}^{-}-\mathrm{N}$ distribution uniformities throughout the soil profile was investigated by carrying out two tomato field experiments. The treatments of one tomato experiment were NPI with $-5 \mathrm{kPa}$ (F1W) and furrow irrigation (F1CK). We also carried out NPI with $-5 \mathrm{kPa}$ (F2W), furrow irrigation (F2CK), and drip irrigation (F2D) in another tomato experiment. The results showed that cumulative water application under $\mathrm{N} 1$ was higher than under N0 in the PW1, PW2, and PW3 treatments in the cucumber experiment. Volumetric soil water content under the NPI system was more stable during the vegetative growth period than under traditional irrigation. The NPI system also increased yields under appropriate pressures $(-10-0 \mathrm{kPa})$ compared to the PCK treatment in the cucumber experiment. The NPI in the two tomato experiments reduced fertilizer inputs and irrigation compared to furrow irrigation and drip irrigation. However, the irrigation method had no significant influence on the tomato yield in the two tomato experiments.
\end{abstract}

\section{Introduction}

The limited supply of fresh water for irrigation is becoming an increasing global challenge along with global warming and rapid population expansion (Flörke et al., 2018; Yang et al., 2019). Agricultural irrigation accounts for approximately $60 \%$ of global water use (Gan et al., 2013; Henriques et al., 2008; Rost et al., 2008). Therefore, the efficient and reasonable use of water for irrigation is a major challenge to reduce water consumption while maintaining yields (Quemada and Gabriel, 2016). To alleviate the pressure on water resources, efficient irrigation management should be adopted to promote the sustainable development of irrigated agriculture.

The primary task of irrigation is to provide suitable amounts of water to the crops according to crop demand (Montesano et al., 2018). However, water supply often exceeds crop demand or soil water holding capacity, which could lead to low water use efficiency (Thompson et al., 2007; Wang et al., 2018; Zotarelli et al., 2009a, 2009b). Improvements in irrigation techniques (e.g. sprinkler and drip irrigation) and scheduling are important components of efficient irrigation management because they can reduce water consumption. Currently, the most

\footnotetext{
* Correspondence to: Institute of Agricultural Resources and Regional Planning, Chinese Academy of Agricultural Sciences, No. 12 Zhongguancun South Street, Haidian District, Beijing 100081, PR China.

E-mail addresses: wuxueping@caas.cn (X. Wu), longhuaiyu@caas.cn (H. Long).
} 
common criteria for irrigation scheduling are based on crop evapotranspiration (ETc), plant physiological properties, and soil water status measurements (Domínguez-Niño et al., 2020; Knipper et al., 2019; Tuccio et al., 2019).

Although ETc-based irrigation management has been extensively studied, it is still problematic because it cannot react to rapid changes in climatic conditions and to different soil textures (Davis and Dukes, 2010; Isidoro and Grattan, 2011; Knipper et al., 2019). Many studies have shown that physiological measurements (e.g. net photosynthetic rate, stomatal conductance, and transpiration rate) could be used to determine the water requirement status of plants (Nakhforoosh et al., 2016; Tuccio et al., 2019). However, this approach is still limited by many theoretical and practical difficulties and cannot be used alone to determine the appropriate water supply volume (Jones, 2004; Rallo et al., 2017). The measurement of soil water status, as volumetric water content or soil matric potential, has been widely used for irrigation scheduling to improve yield and water use efficiency (Contreras et al., 2017; Domínguez-Niño et al., 2020; Létourneau et al., 2015). Nevertheless, it is still difficult to maintain soil water content in a fixed range that is suitable for vegetable growth during the whole growth period. The method may not be efficient when using some conventional irrigation techniques because volumetric soil water content under these techniques has large spatial and temporal variabilities that can detrimentally affect vegetable growth (Hendrickx et al., 1994; Zhao et al., 2012). Reducing the variability can improve the absorption and utilization of soil water and $\mathrm{NO}_{3}^{-}-\mathrm{N}$ by vegetables (Barber, 1995; Zhou et al., 2018) and reduce water and $\mathrm{NO}_{3}^{-}-\mathrm{N}$ losses due to deep percolation (Simonne et al., 2014).

Negative pressure irrigation (NPI) integrates the advantages of the aforementioned methods and improves vegetable yield and water use efficiency (Li et al., 2017b; Yang et al., 2020). The pressure of the water supply in the NPI system is set as an appropriate negative value according to the soil matric potential and attempts to meet the water requirements for vegetable growth. Regardless of soil type and climatic conditions, NPI can supply irrigation water accurately and continuously when soil water content decreases due to evapotranspiration (Moniruzzaman et al., 2011; Wang et al., 2019a, 2019b). Li et al. (2017a) studied the changes in soil water content during cucumber growth period in a pot experiment using the NPI system and found that the system significantly reduced the fluctuation of volumetric soil water content during the cucumber growth period compared to artificial irrigation with a measuring cylinder. Yang et al. (2020) also found that the soil water content range under water supply pressure of $-4 \mathrm{kPa},-8 \mathrm{kPa}$, and $-12 \mathrm{kPa}$ were $26.3-27.2 \%, 23.5-24.6 \%$, and $18.1-19.9 \%$ during the crown daisy growth period in a pot experiment, respectively. The optimum soil matric potential for each crop species is different (Contreras et al., 2017). Some studies have shown that the optimum NPI water supply pressure for rapeseed (Zhao et al., 2019), crown daisy (Yang et al., 2020), cucumber (Zhao et al., 2017), and tomato (Gao et al., 2019; Li et al., 2019) were $-5 \mathrm{kPa},-8 \mathrm{kPa},-3$ to $-5 \mathrm{kPa}$, and $-5 \mathrm{kPa}$, respectively. Both cucumber and tomato are sensitive to soil water content and N supply (Badr et al., 2016; Wang et al., 2019a, 2019b). Therefore, cucumber and tomato were used in our study to reveal the effect of NPI on vegetable water productivity and nitrogen use efficiency. Although the effect of NPI on vegetable crop growth has been extensively studied (Li et al., 2017b; Yang et al., 2020; Zhao et al., 2017), it is still not clear how NPI improves water productivity and nitrogen use efficiency through its water supply characteristics.

The effects of soil water and nitrate distribution uniformities on vegetable growth may be as important as the soil water and available nitrogen contents. Zhou et al. (2018) found that the distribution uniformity of soil $\mathrm{NO}_{3}^{-}-\mathrm{N}$ had a closer relationship with maize yield than soil water content and $\mathrm{NO}_{3}^{-}-\mathrm{N}$ concentration when a drip irrigation system was used in a field experiment. The distribution uniformity of soil water could increase crop yield (Zhao et al., 2012), but no relationship between the uniformity and crop yield was also found (Zhou et al., 2018).
Although the result is inconsistent, the distribution uniformities of soil water and nitrate remain one of the most important considerations when designing irrigation systems, such as drip irrigation and sprinkler irrigation (Kang et al., 2000; Li and Liu, 2011). However, previous studies of the NPI system have focused on the effect of soil water content (Yang et al., 2020) and $\mathrm{NO}_{3}^{-}-\mathrm{N}$ concentration (Li et al., 2019) on vegetable yield rather than the soil water and $\mathrm{NO}_{3}^{-}-\mathrm{N}$ distribution uniformities.

In our study, a cucumber pot experiment was carried out because it was easier to control the crop growth environment compared to a field experiment. The aims were to reveal the NPI water supply characteristics and their effect on crop growth. Two tomato experiments were also conducted under greenhouse conditions to further explore the relationship between crop growth and the soil water content and $\mathrm{NO}_{3}^{-}-\mathrm{N}$ distribution uniformities. The objective was to reveal the mechanistic behavior of the NPI system and its effects on soil water and nitrogen movement, vegetable yield, water productivity, and nitrogen use efficiency.

\section{Materials and methods}

\subsection{Study site}

The study consisted of a cucumber pot experiment in a rain shelter house located at the Chinese Academy of Agricultural Sciences $\left(39.9^{\circ} \mathrm{N}\right.$, $116.3^{\circ} \mathrm{E}$ ) in Beijing, China. Two tomato experiments in two greenhouses located in Shijiazhuang $\left(38.2^{\circ} \mathrm{N}, 114.9^{\circ} \mathrm{E}\right)$ (tomato 1$)$, Heibei Province, and Jinan $\left(36.6^{\circ} \mathrm{N}, 117.1^{\circ} \mathrm{E}\right)$ (tomato 2$)$, Shandong Province, China, respectively. The three experimental sites have a temperate continental monsoon climate. According to the USDA texture classification, the soil used in cucumber and tomato 1 experiments was sandy loam soil and the soil texture for the tomato 2 experiment was silty clay loam. The basic soil physical and chemical properties are shown in Table 1.

\subsection{NPI system and experimental design}

The NPI system (Patents, US 4235561A and China ZL201610329413.3) has three main components: a crop growing area, a water tank, and a negative pressure generator (Fig. 1). The emitter was a clay (kaolin) pipe that had an inner diameter of $11 \mathrm{~mm}$, an outer diameter of $18 \mathrm{~mm}$, and was $150 \mathrm{~mm}$ long. The saturated hydraulic conductivity of the emitter is $0.019 \mathrm{~cm} \mathrm{~h}^{-1}$ (Wang et al., 2019a, 2019b) and it was used in both the cucumber and tomato experiments. The burial depth of the emitter was $15 \mathrm{~cm}$ in the three experiments and the space between two emitters in the tomato experiments was $30 \mathrm{~cm}$. The NPI system is in a state of dynamic balance between the soil matric potential and irrigation pressure. The NPI system starts to irrigate when soil water is consumed because soil water consumption reduces soil matric potential and soil water moves from the high potential region (irrigation emitter) to a low potential region (soil). The NPI system will automatically stop irrigating when the soil matric potential is equal to the irrigation pressure (Wang et al., 2017). Therefore, the NPI system is different from other conventional irrigation methods (e.g. sprinkler irrigation and drip irrigation) because they have a shorter irrigation time, whereas the irrigation water under the NPI system is supplied according to the soil water status. The air pressure in the water tank decreases due to water level reductions and then the air in the gas canister moves into the water tank to keep the air pressure in the water tank stable. The solenoid valve, controlled by a pressure switch, is opened to let atmospheric air into the gas canister so that the pressure is consistent with the negative pressure set by the pressure switch. The negative pressure is called the negative water supply pressure of the NPI system. In the two tomato experiments, we used heavy liquid-type equipment as a negative pressure generator to control the negative pressure of the system. Detailed information about the NPI system working principle is shown in Wang et al. (2019).

In the cucumber experiment (Fig. 2a and b), each pot (length $45 \mathrm{~cm}$, 
Table 1

Soil physical and chemical properties in 0-20 cm layer for cucumber and tomato experiments.

\begin{tabular}{|c|c|c|c|c|c|c|c|c|c|}
\hline \multirow[t]{2}{*}{ Experiment } & \multicolumn{3}{|c|}{ Soil particle size distribution (\%) } & \multicolumn{3}{|c|}{ Available soil nutrient $\left(\mathrm{mg} \mathrm{kg}^{-1}\right)$} & \multirow[t]{2}{*}{ SOC $\left(\mathrm{g} \mathrm{kg}^{-1}\right)$} & \multirow[t]{2}{*}{ Bulk density $\left(\mathrm{g} \mathrm{cm}^{-3}\right)$} & \multirow[t]{2}{*}{ Field capacity (\%) } \\
\hline & $20-200 \mu \mathrm{m}$ & $2-20 \mu \mathrm{m}$ & $<2 \mu \mathrm{m}$ & $\mathrm{N}$ & $\mathrm{P}$ & $\mathrm{K}$ & & & \\
\hline Cucumber & 56.7 & 37.2 & 6.1 & 57 & 22 & 112 & 10.1 & 1.44 & $25.7 \%$ \\
\hline Tomato 1 & 62.9 & 30.7 & 6.4 & 72 & 19 & 99 & 9.2 & 1.35 & $24.5 \%$ \\
\hline Tomato 2 & 26.1 & 58.8 & 15.1 & 95 & 47 & 178 & - & 1.28 & $28.9 \%$ \\
\hline
\end{tabular}

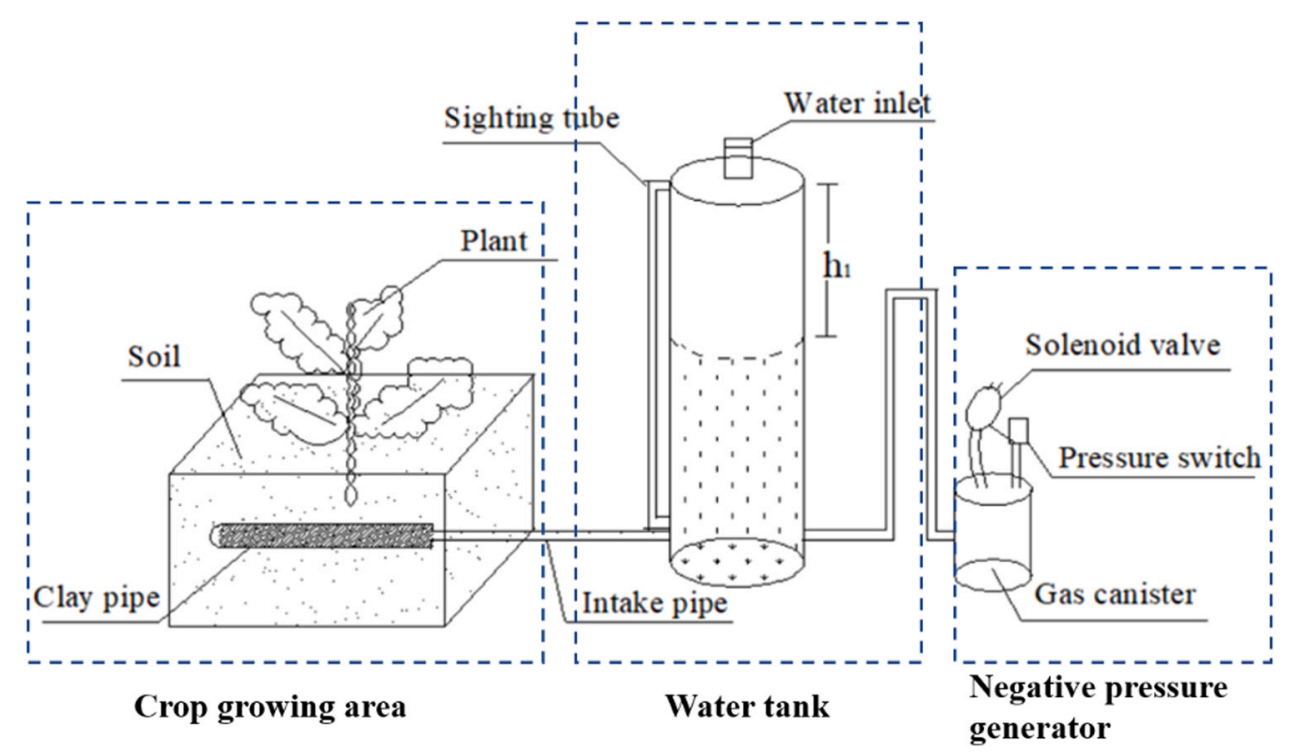

Fig. 1. The schematic of a negative pressure irrigation system.

width $28 \mathrm{~cm}$, depth $26 \mathrm{~cm}$ ) was filled with $30 \mathrm{~kg}$ soil. Five treatments were applied, which were water supply pressures of $0 \mathrm{kPa}$ (PW1), $-5 \mathrm{kPa}$ (PW2), $-10 \mathrm{kPa}$ (PW3), and $-15 \mathrm{kPa}$ (PW4) under the NPI system and conventional irrigation (PCK), nitrogen application (N1) and no application (N0) treatments were also applied to each irrigation treatment. There were three replicates for each treatment ( 30 pots in total) and a completely randomized design was used. In the PCK treatment, the soil water status in the $0-15 \mathrm{~cm}$ layer was measured every three days by a volumetric soil water content (VSWC) sensor (ECA-SW1, Tuopu, Beijing, China) and its measuring position was $5 \mathrm{~cm}$ from the long side of the pot. The VSWC was maintained by manually watering the soil surface with a measuring cylinder to $70-90 \%$ of field capacity under the PCK treatment, which corresponded to a VSWC range of $18.0-23.1 \%$. The irrigation amounts in the PCK treatment at the seeding, flowering, fruit enlarging, and fruit maturity stages were 166, 239, 423, and $156 \mathrm{~mm}$, respectively. The soil water content in each PCK treatment pot was calculated according to Li et al. (2019) and the water consumption was calculated from the irrigation water and the variation in soil water content. The irrigation water volume under the NPI system was obtained from the water level variation in the water bucket (Fig. 1). The cucumber experimental period was from June to October 2015 and the cucumber seedlings with Zhongnong No. 106 (China Vegetable Seed Co. Ltd, Beijing, China) were transplanted at the 2-3 leaf stage (one plant each pot). The fertilizer in the nitrogen application (N1) treatment was applied at $714 \mathrm{~kg} \mathrm{~N} \mathrm{ha}^{-1}, 587 \mathrm{~kg} \mathrm{~K} \mathrm{ha}^{-1}$, and $206 \mathrm{~kg} \mathrm{P} \mathrm{ha}^{-1}$ using urea, potassium sulfate, and calcium superphosphate, respectively (Table 2). Each pot without nitrogen application (NO) was supplied with the same $\mathrm{K}$ and $\mathrm{P}$ rates. All $\mathrm{P}$ and $40 \%$ of the $\mathrm{N}$ and $\mathrm{K}$ were supplied as basal fertilizer. The rest of the $\mathrm{N}$ and $\mathrm{K}$ were supplied by adding them to the water supply tank on three separate occasions, which were the 9 August 2015 (flowering stage), 23 August 2015 (fruit enlarging stage), and 8 September 2015 (fruit maturity stage). The rest of the fertilizer in the PCK treatment was a one-time application, while $\mathrm{N}$ and $\mathrm{K}$ were continuously applied using the NPI system with the concentrations of $\mathrm{N}$ and $\mathrm{K}$ at 27.2 and $9.0 \mathrm{mmol} \mathrm{L}^{-1}$ for cucumber, respectively.

The tomato 1 field experiment (Fig. 2c and d) was a completely randomized design with two irrigation treatments and three replications. The two treatments were NPI with $-5 \mathrm{kPa}(\mathrm{F} 1 \mathrm{~W})$ and furrow irrigation (F1CK). The tomato 2 field experiment had three treatments with a completely randomized design and three replications. The three treatments were NPI with $-5 \mathrm{kPa}$ (F2W), furrow irrigation (F2CK), and drip irrigation (F2D). There were nitrogen application and no application treatments for each irrigation treatment in the tomato 1 experiment. In the F1CK, F2CK, and F2D treatments, the same method utilized in the cucumber PCK treatment was used to control the VSWC in the 0-15 cm layer by furrow irrigation or drip irrigation every $5 \mathrm{~d}$ and maintained the soil water status at between $70 \%$ and $90 \%$ of field capacity, which corresponded to VSWC ranges of $17.2-22.1 \%$ and $20.2-26.0 \%$ in tomato 1 and 2 experiments, respectively. The irrigation amounts in the F1CK treatment at the seeding, flowering, fruit enlarging, and fruit maturity stages were $23.9,67.4,51.9$, and $42.8 \mathrm{~mm}$, respectively. The irrigation amounts of F2D were 57.8, 43.7, 47.1, and $52.0 \mathrm{~mm}$ at the four growth stages, respectively. The amounts of F2CK at the four stages were 77.5, $53.3,63.2$, and $65.9 \mathrm{~mm}$, respectively. A water supply pressure of $-5 \mathrm{kPa}$ was used in the two tomato experiments, which is an appropriate pressure for tomato growth according to previous studies (Gao et al., 2019; Li et al., 2019). The size of each plot in the two tomato experiments was $6.0 \mathrm{~m} \times 1.4 \mathrm{~m}$ and an impermeable PCV board $(4 \mathrm{~mm})$ was vertically buried in the $0-60 \mathrm{~cm}$ layer between two plots to prevent lateral infiltration. Each plot contained two rows, with 20 plants in each row in the two tomato experiments. The tomato seedlings (Xianke 8) were transplanted at the 2-3 leaf stage. The growth period was from August to December 2017 for the tomato 1 experiment and from September 2017 to May 2018 for the tomato 2 experiment. The N, K, and $\mathrm{P}$ fertilizer inputs in F1CK treatment were $450 \mathrm{~kg} \mathrm{~N} \mathrm{ha}^{-1}, 215 \mathrm{~kg} \mathrm{~K} \mathrm{ha}^{-1}$, and $97 \mathrm{~kg} \mathrm{Pha}^{-1}$ using urea, potassium sulfate, calcium superphosphate, 

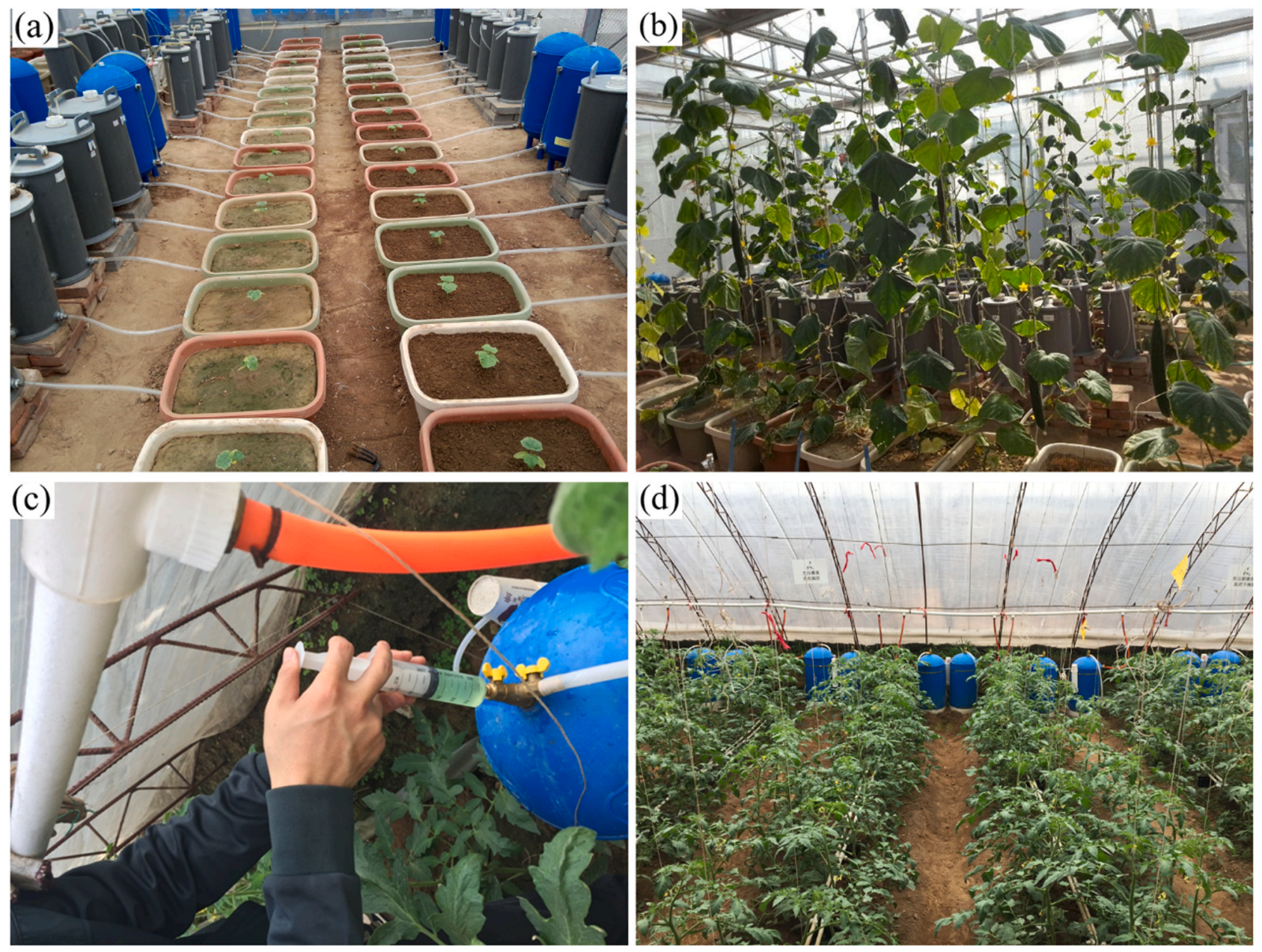

Fig. 2. Photographs of the negative pressure (NPI) system in the cucumber (a and b) and tomato (c and d) experiments. Seeding stage of cucumber (a), Fruiting stage of cucumber (b), Fertilizer management of tomato (c), and Flowing stage of tomato (d).

Table 2

The fertilizer inputs in the cucumber and two tomato experiments.

\begin{tabular}{lllc}
\hline Treatment & $\mathrm{N}\left(\mathrm{kg} \mathrm{ha}^{-1}\right)$ & $\mathrm{K}\left(\mathrm{kg} \mathrm{ha}^{-1}\right)$ & $\mathrm{P}\left(\mathrm{kg} \mathrm{ha}^{-1}\right)$ \\
\hline PW & 714 & 587 & 206 \\
PCK & 714 & 587 & 206 \\
F1W & 315 & 150 & 68 \\
F1CK & 450 & 215 & 97 \\
F2W & 480 & 264 & 194 \\
F2CK & 660 & 430 & 262 \\
F2D & 520 & 289 & 211 \\
\hline
\end{tabular}

respectively. For the F2CK, the three fertilizer inputs were $660 \mathrm{~kg} \mathrm{~N}$ $\mathrm{ha}^{-1}, 430 \mathrm{~kg} \mathrm{~K} \mathrm{ha}^{-1}, 262 \mathrm{~kg} \mathrm{P} \mathrm{ha}^{-1}$. The three fertilizer inputs of the F2D treatment were $520 \mathrm{~kg} \mathrm{~N} \mathrm{ha}^{-1}, 289 \mathrm{~kg} \mathrm{~K} \mathrm{ha}^{-1}, 211 \mathrm{~kg} \mathrm{P} \mathrm{ha}^{-1}$. The three fertilizer inputs of the NPI were the least in the tomato 2 experiment. Table 2 showed the detailed information about the fertilizer inputs under the three experiments. The concentrations and the fertilization method under the NPI system in the two tomato experiments were the same as the cucumber experiment. A total of $60 \% \mathrm{~N}$ and $\mathrm{K}$ fertilizers were applied by adding them to the water supply tank three times on 12 October 2017 (flowering stage), 28 October 2017 (fruit enlarging stage), and 12 November 2017 (fruit maturity stage) in the tomato 1 experiment. For the tomato 2 experiment, the three dates at the three growth stages for applying $\mathrm{N}$ and $\mathrm{K}$ fertilizers were 17 November 2017, 1 January 2018, and 20 February 2018.

\subsection{Sampling and measurements}

The VSWC in the $0-15 \mathrm{~cm}$ layer was measured by a soil water sensor (ECA-SW1, Tuopu, Beijing, China) in the cucumber experiment between $17: 00$ and 18:00 every 8 days so that the changes in VSWC during the cucumber growth period were determined. The cumulative water application was recorded every day at 17:00 by reading the sighting tube for the water level in the NPI system water tank (Fig. 1). The irrigation water was measured by a measuring cylinder in the PCK treatment and by a water meter in the F1CK, F2CK, and F2D treatments.

The soil water and $\mathrm{NO}_{3}^{-}-\mathrm{N}$ distributions were measured on four sampling dates in the three experiments and the dates corresponded with the flowering stage, fruit enlarging stage, fruit maturity stage, and late fruit harvesting stage. The four sampling dates were 14 August 2015, 27 August 2015, 11 September 2015, and 30 September 2015 in the cucumber experiment, 15 October 2017, 1 November 2017, 15 November 2017, and 1 December 2017 in the tomato 1 experiment, and 20 November 2017, 4 January 2018, 23 February 2018, and 28 March 2018 in the tomato 2 experiment. It should be noted that all the sampling times in the F1CK, F2CK, and F2D treatments were on the third day after irrigation, hence, the interval between the sampling and the previous irrigation under these treatments is the same. The samples were collected using a hand auger with a $2 \mathrm{~cm}$ internal diameter at three depths in the three experiments. The three depths were $8 \mathrm{~cm}, 16 \mathrm{~cm}$, and $24 \mathrm{~cm}$ in the cucumber experiment and $10 \mathrm{~cm}, 20 \mathrm{~cm}$, and $30 \mathrm{~cm}$ in the two tomato experiments. The soil samples were shaken and extracted in $2 \mathrm{M}$ KCL (1:5 soil to solution ratio) for $1 \mathrm{~h}$ and then the soil $\mathrm{NO}_{3}^{-}-\mathrm{N}$ 
concentration was measured by a continuous flow auto analyzer (SEAL AutoAnalyzer 3, Norderstedt, Germany).

The Christiansen uniformity coefficients (CU) for soil water and $\mathrm{NO}_{3}^{-}$ $\mathrm{N}$ in the soil profile were used to evaluate the distribution uniformities of the soil water and $\mathrm{NO}_{3}^{-}-\mathrm{N}$. The $\mathrm{CU}$ was first proposed by Christiansen (1942) to calculated the system uniformity of overlapping sprinklers. However, some previous studies have successfully used it in furrow irrigation (Kang et al., 2000), drip irrigation (Lopes et al., 2019), and micro-irrigation (Kumar et al., 2009) systems. The CU can also be used to quantify the uniformities of plant height (Zhao et al., 2012), soil water content with depth (Kang et al., 2000), nitrogen uptake (Guan et al., 2013), soil nitrogen (Zhou et al., 2018). The CU of the soil water was calculated as follows:

CUof soilwater $=1-\frac{\sum_{i=1}^{n}\left|\theta_{i}-\bar{\theta}\right|}{n \bar{\theta}}$

where the $\mathrm{CU}$ of soil water is the soil water distribution uniformity in the 0-24 cm layer of the cucumber experiment and the 0-30 cm layer in the two tomato experiments and ranges from 0 (low uniformity) to 1 (high uniformity); $\bar{\theta}$ is the average observed VSWC at the three soil depths and $\mathrm{n}=3$ in this study. The $\mathrm{CU}$ of the soil $\mathrm{NO}_{3}^{-}-\mathrm{N}$ is also obtained from the aforesaid equation.

Tomato yield was determined by harvesting ten contiguous plants from each plot. Volumetric soil water content in the $0-100 \mathrm{~cm}$ soil layer was measured at the beginning and the end of the two tomato experiments, which was used to calculate soil water balance and then enabled estimation of total water use. Water productivity (WP) was calculated as the vegetable yield $(\mathrm{kg})$ divided by total water consumption $\left(\mathrm{m}^{3}\right)$ (Fernández et al., 2020; Kijne and Barker, 2003) and detailed information about how to calculate total water consumption can be found in the studies (Li et al., 2019; Yang et al., 2020). Nitrogen use efficiency (NUE) was calculated using the following equation:

$N U E=\left(Y_{n}-Y_{0}\right) / N$

where $Y_{n}$ and $Y_{O}$ are the vegetable yields $(\mathrm{kg})$ in the nitrogen application and no application treatments, respectively, and $\mathrm{N}$ is the applied nitrogen $(\mathrm{kg})$. Detailed information about how to calculate NUE can be found in Badr et al. (2016).

\subsection{Statistical analysis}

The variables (soil water content, soil $\mathrm{NO}_{3}^{-}-\mathrm{N}$, $\mathrm{CU}$ of soil water and $\mathrm{NO}_{3}^{-}-\mathrm{N}$, yield, WP, and NUE) were analyzed among the treatments in the cucumber and two tomato experiments, along with repeated measures during the growth period at the three soil depths. Analyses of variance (ANOVA) was used and the least significant difference (LSD) test ( $\mathrm{p} \leq 0.05$ ) was conducted using SAS 9.4 software (SAS Institute Inc., Cary, North Carolina, USA) to evaluate the differences among treatments for soil water content, soil $\mathrm{NO}_{3}^{-}-\mathrm{N}, \mathrm{CU}$ of soil water and $\mathrm{NO}_{3}^{-}-\mathrm{N}$, yield, WP, and NUE. The general linear model procedure (PROC CORR) was used to determine initial relationships among these variables.
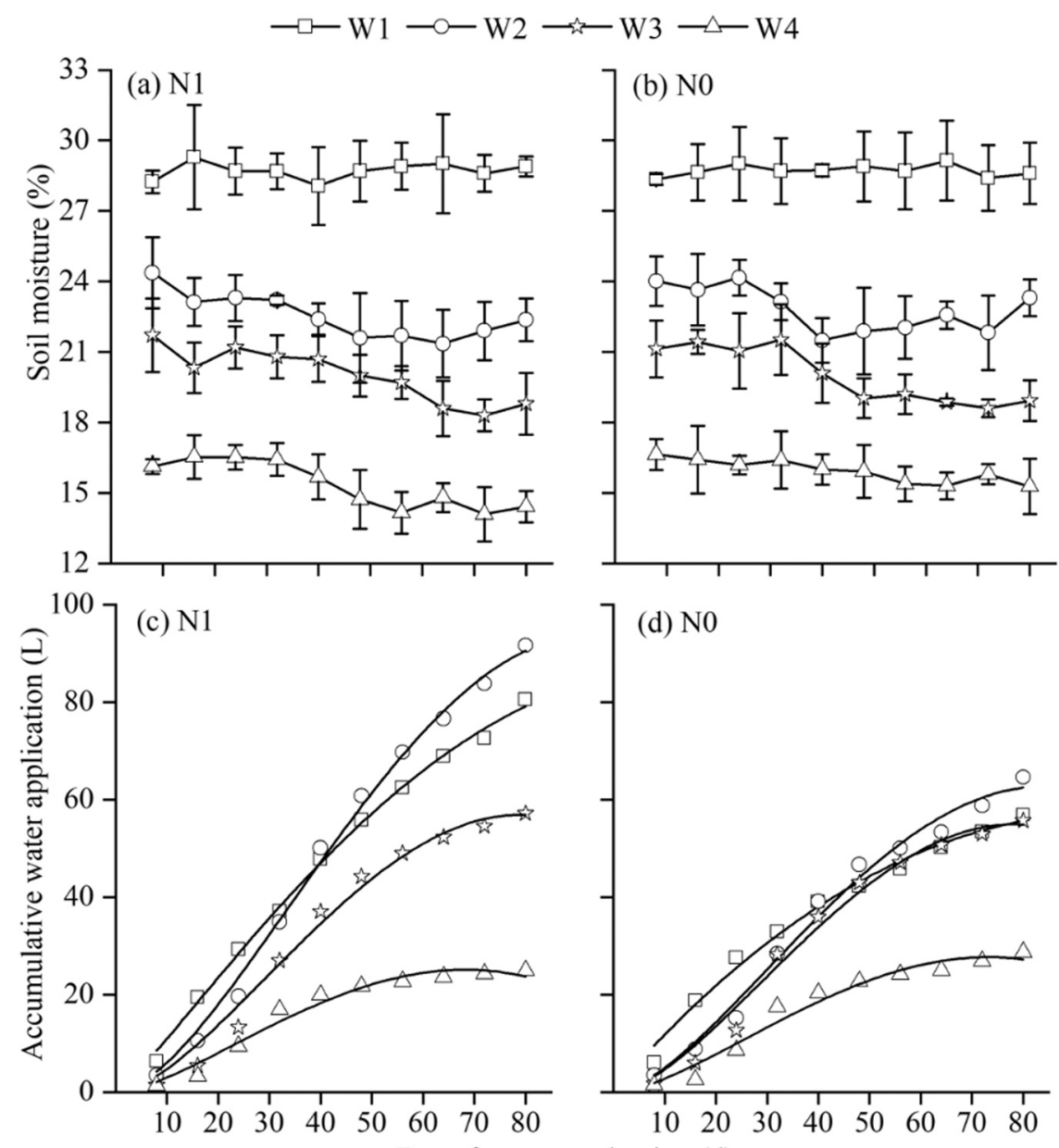

(d) N0

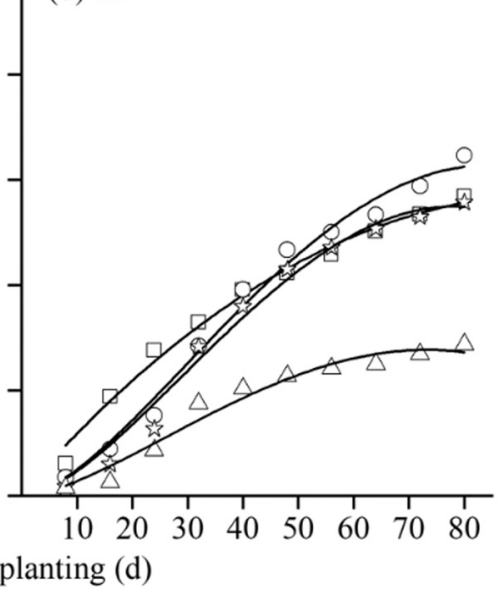

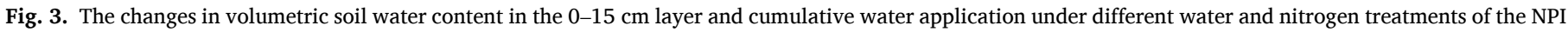
system during the cucumber growth period in the cucumber experiment. Vertical bars represent standard errors. 


\section{Results}

3.1. Temporal dynamics for volumetric soil water content (VSWC) and cumulative water application

The temporal dynamics for VSWC (0-15 cm layer) under the NPI system for the nitrogen application (N1) and no application (N0) treatments were shown in Fig. 3a and b, respectively. The water supply pressure had a significant influence on VSWC during the same growth period ( $\mathrm{p}<0.05$ ), whereas nitrogen application had no significant effect on VSWC (p > 0.05). The VSWC at $0 \mathrm{kPa}$ (PW1), $-5 \mathrm{kPa}$ (PW2), $-10 \mathrm{kPa}$ (PW3), and -15 kPa (PW4) were 27.8-29.3\%, 21.4-24.4\%, 18.3-21.7\%, and $14.1-16.4 \%$ during the cucumber growth periods, respectively.

The temporal dynamics for cumulative water applications were shown in Fig. 3c and d. The cumulative water applications for PW1N1 and PW2N1 were 56.6\% and 41.8\% higher than for PW1N0 and PW2N0 at 80 days after transplanting, respectively. However, there was no significant difference between PW3N1 and PW3N0. The PW4N1 treatment was $13.2 \%$ lower than PW4NO. At the same nitrogen application level, the cumulative water application decreased as the negative pressure of the water supply increased (PW2 $>$ PW3 $>$ PW4). Furthermore, the cumulative water application in PW1 was higher than in PW2 during the $0-40$ day period $(\mathrm{p}<0.05)$, but less than in PW2 during the $40-80$ day period $(\mathrm{p}<0.05)$.

\subsection{Effect of water supply pressure on VSWC and cumulative water application}

The relationships between VSWC and water supply pressure under nitrogen application and no nitrogen application treatments were shown in Fig. $4 \mathrm{a}$ and $\mathrm{b}$, respectively. There was a significant exponential relationship between the two variables, regardless of whether there was nitrogen application or no application $(p<0.001)$. The VSWC decreased as the negative pressure of the water supply increased (PW1 > PW2 > PW3 > PW4) under both nitrogen application conditions. There was a parabolic relationship between cumulative water application and water supply pressure in both nitrogen treatments (Fig. 4c and d). The main reason was that the water supply pressure controlled VSWC (Fig. 3) and less water will be supplied under low soil water content throughout the growth period. Cumulative water application increased at first and then decreased as the negative pressure of the water supply increased. The $\mathrm{N} 1$ treatment had a higher cumulative water application value than $\mathrm{N} 0$ when the water supply pressure was between -5 and $0 \mathrm{kPa}$.

\subsection{The VSWC distribution}

The VSWC in the $0-24 \mathrm{~cm}$ layer during the four cucumber growth periods are shown in Fig. $5 \mathrm{a}-\mathrm{d}$. The VSWC at $8 \mathrm{~cm}, 16 \mathrm{~cm}$, and $24 \mathrm{~cm}$ depths decreased as the negative pressure of the water supply increased under the NPI system. Their ranges for PW1, PW2, PW3, PW4, and PCK in the $0-24 \mathrm{~cm}$ layer during the four growth periods were $25.6-28.9 \%$, $19.4-22.3 \%, 17.0-19.7 \%, 12.9-15.7 \%$, and $17.1-24.8 \%$, respectively. The VSWC of tomato 1 and 2 experiments in the $0-30 \mathrm{~cm}$ layer are shown in Fig. 5e-h and $\mathrm{i}-1$, respectively. The VSWC distribution in the $0-30 \mathrm{~cm}$ layer was mainly controlled by the location of the clay pipe in the NPI system (F1W and F2W), and VSWC at $20 \mathrm{~cm}$ depth was higher than at 10 and $30 \mathrm{~cm}$. The VSWC in F1CK treatment was higher in the
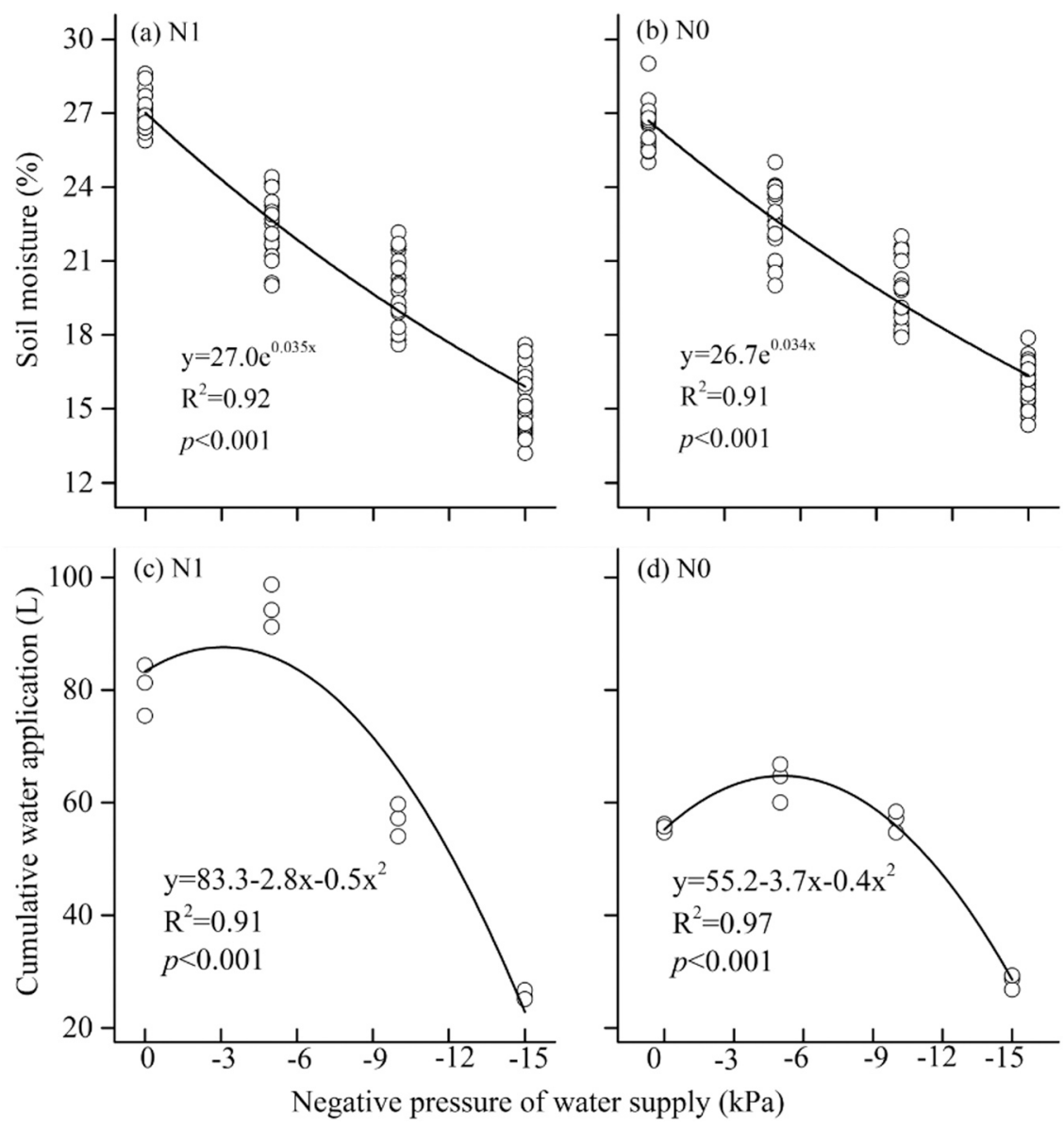

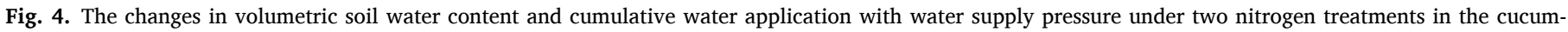
ber experiment. 


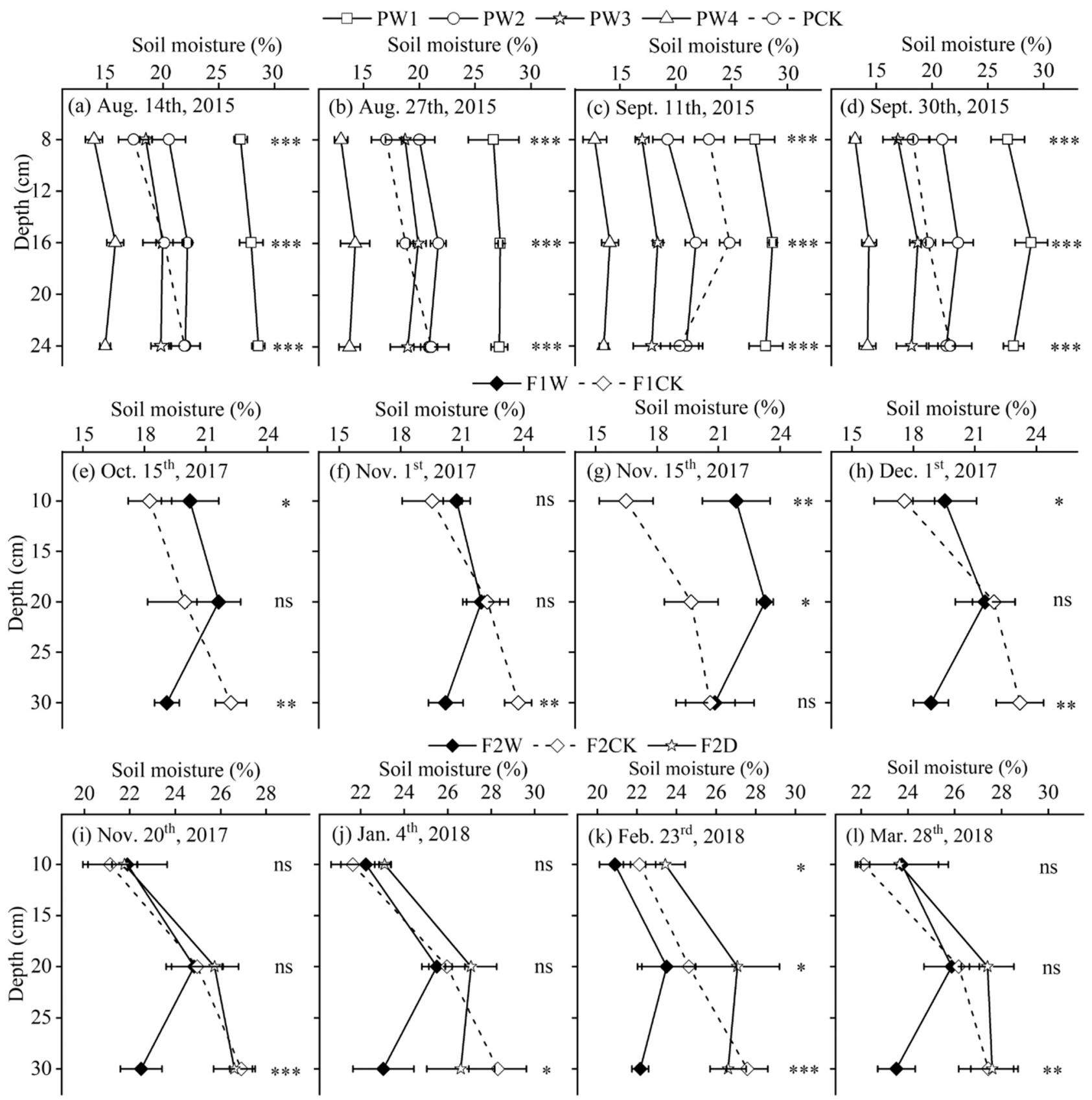

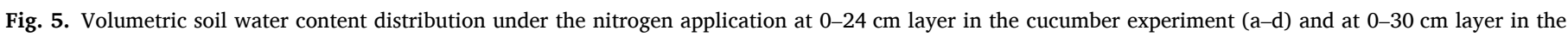

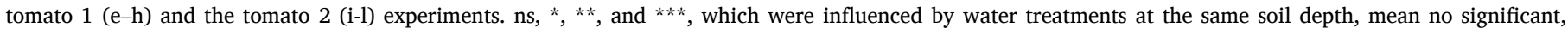
$\mathrm{P}<0.05, \mathrm{P}<0.01$, and $\mathrm{P}<0.001$, respectively.

$30 \mathrm{~cm}$ layer than in the F1W treatment, except for 15 November. In the tomato 2 experiment, the VSWC of F2W was also lower than F2CK and F2D treatment during the growth period. In addition, the variation trend showed that the VSWC of F1CK and F2CK treatments increased with soil depth. The VSWC ranges of F1W and F1CK in the $0-30 \mathrm{~cm}$ layer over the four growth periods were $19.3-23.2 \%$ and $16.7-23.9 \%$, respectively, and they were $20.9-25.8 \%, 21.1-27.6 \%$, and $21.8-27.3 \%$ for $\mathrm{F} 2 \mathrm{~W}$, F2CK, and F2D treatments, respectively.

\subsection{Soil $\mathrm{NO}_{3}^{-}-\mathrm{N}$ distribution}

In the cucumber experiment (Fig. 6a-d), the average value for soil $\mathrm{NO}_{3}^{-}-\mathrm{N}$ in the $0-24 \mathrm{~cm}$ layer increased as the negative pressure of the water supply (PW1 $<$ PW2 $<$ PW3 $<$ PW4). Soil $\mathrm{NO}_{3}^{-}-\mathrm{N}$ in the PCK treatment was less than in the PW2, PW3, and PW4 treatments at $8 \mathrm{~cm}$ depth over the four growth periods, while PCK had more soil $\mathrm{NO}_{3}^{-}-\mathrm{N}$ than PW1, PW2, and PW3 at $24 \mathrm{~cm}$ depth. The same trend occurred in the two tomato experiments (Fig. 6e-h). Soil $\mathrm{NO}_{3}^{-}-\mathrm{N}$ in FCK was less than in FW at $10 \mathrm{~cm}$ depth over the four growth periods. However, F1CK was higher than $\mathrm{F} 1 \mathrm{~W}$ at $30 \mathrm{~cm}$ depth and the soil $\mathrm{NO}_{3}^{-} \mathrm{N}$ at this soil layer under F2CK and F2D treatments was also higher than F2W. Furthermore, in the three experiments, soil $\mathrm{NO}_{3}^{-}-\mathrm{N}$ increased with soil depth under the traditional irrigation treatments (e.g. PCK, F1CK, F2CK, and F2D).

\subsection{The $\mathrm{CU}$ for soil water and $\mathrm{NO}_{3}^{-}-\mathrm{N}$}

The negative pressure irrigation system had higher $\mathrm{CU}$ for soil water and $\mathrm{NO}_{3}^{-}-\mathrm{N}$ than conventional irrigation over all the growth period in the 


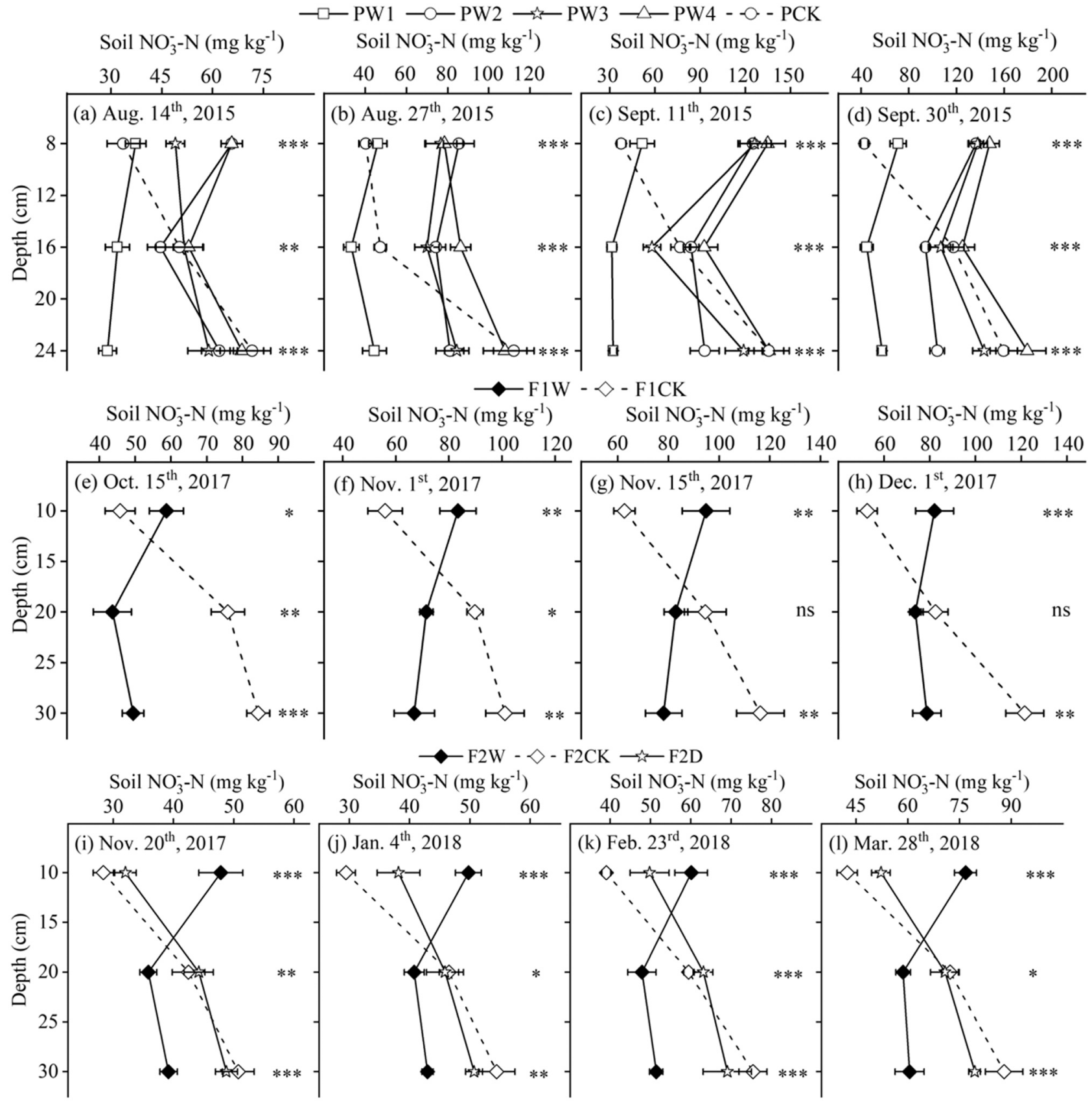

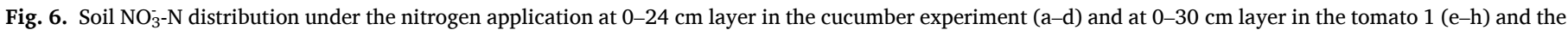

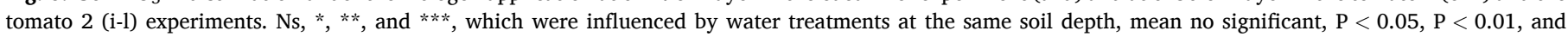
$\mathrm{P}<0.001$, respectively.

cucumber (Fig. 7a and d) and tomato (Fig. 7b, c, e, and f) experiments. The average CU for soil water in the PW1, PW2, PW3, and PW4 treatments at $0-24 \mathrm{~cm}$ depth during the four growth periods were $5.3 \%$, $4.0 \%, 4.1 \%$, and $3.4 \%$ higher than for the PCK treatment, respectively. The average soil water CU of F1W treatment was $4.4 \%$ higher in the 0-30 cm layer than F1CK and the soil water CU under F2W was $5.2 \%$ and $2.7 \%$ higher than F2CK and F2D treatments, respectively. The CU for soil $\mathrm{NO}_{3}^{-}-\mathrm{N}$ is shown in Fig. $7 \mathrm{~d}-\mathrm{f}$. In the cucumber experiment, the PW1, PW2, PW3, and PW4 treatments had 33.2\%, 37.4\%, 35.0\%, and $37.7 \%$ higher average soil $\mathrm{NO}_{3}^{-}-\mathrm{N}$ CU during the cucumber growth period than the PCK treatment, respectively. The average soil $\mathrm{NO}_{3}^{-}-\mathrm{N} \mathrm{CU}$ for the F1W treatment was $15.5 \%$ higher than F1CK, whereas the soil $\mathrm{NO}_{3}^{-}-\mathrm{N} \mathrm{CU}$ for conventional irrigation on 30 September 2015 decreased by $18.7 \%$ compared with the 14 August 2015 in the cucumber experiment. The CU on the 1 December 2017 decreased by $15.5 \%$ compared with the 15 October 2017 in the tomato 1 experiment. In addition, soil $\mathrm{NO}_{3}^{-}-\mathrm{N} \mathrm{CU}$ for the $\mathrm{F} 2 \mathrm{~W}$ treatment was also higher than F2CK and F2D during the tomato growth period $(\mathrm{p}<0.05)$, which was the same as the tomato 1 experiment.

3.6. Total water supply, yield, water productivity (WP), and nitrogen use efficiency (NUE)

Total water supply, yield, WP, and NUE with nitrogen fertilizer application in the cucumber and tomato experiments were shown in Table 3. The PW2, PW3, and PW4 treatments decreased the total water supply compared to PCK treatment. In the two tomato experiments, negative pressure irrigation also reduced the total water supply 

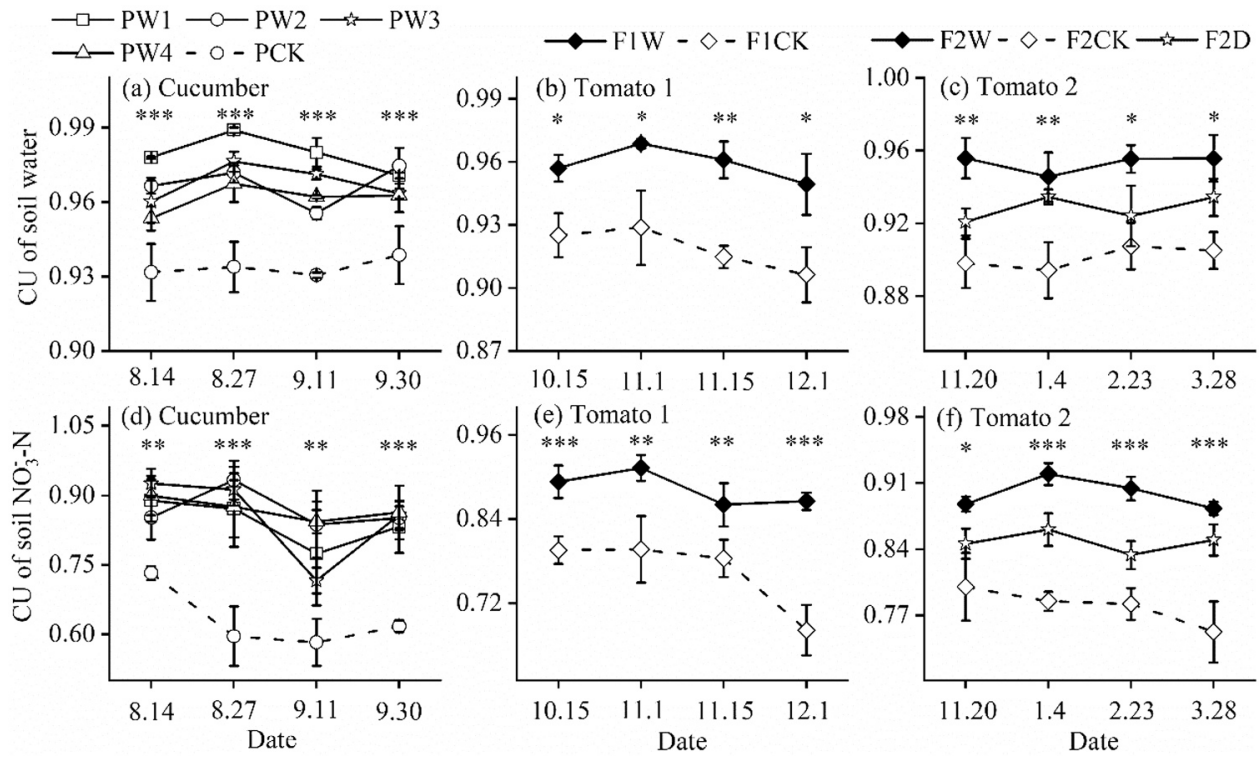

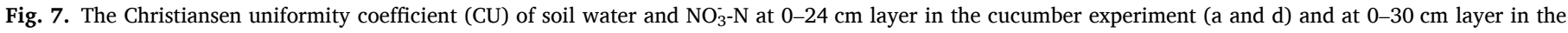

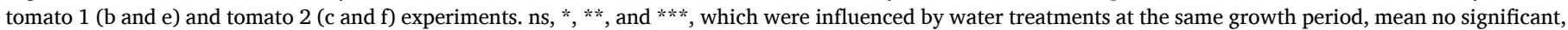
$\mathrm{P}<0.05, \mathrm{P}<0.01$, and $\mathrm{P}<0.001$, respectively.

Table 3

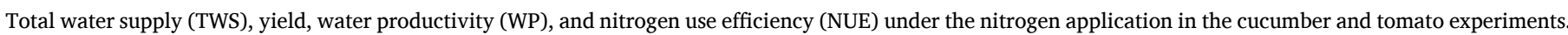

\begin{tabular}{|c|c|c|c|c|c|}
\hline Experiment & Treatment & TWS (mm) & Yield $\left(\mathrm{g}_{\text {plant }}{ }^{-1}\right.$ ) & WP $\left(\mathrm{kg} \mathrm{m}^{-3}\right)$ & NUE (\%) \\
\hline \multirow[t]{5}{*}{ Cucumber } & PW1 & $1058 \pm 73 a$ & $1071 \pm 69 b$ & $14.8 \pm 0.5 c$ & $49.6 \pm 4.7 \mathrm{a}$ \\
\hline & PW2 & $860 \pm 61 b$ & $1551 \pm 85 a$ & $16.5 \pm 1.2 \mathrm{~b}$ & $41.3 \pm 4.0 \mathrm{a}$ \\
\hline & PW3 & $538 \pm 38 c$ & $1100 \pm 51 b$ & $18.7 \pm 1.4 \mathrm{a}$ & $24.3 \pm 3.4 \mathrm{~b}$ \\
\hline & PW4 & $209 \pm 17 d$ & $456 \pm 31 d$ & $19.9 \pm 0.8 \mathrm{a}$ & $12.2 \pm 2.5 \mathrm{~d}$ \\
\hline & PCK & $1118 \pm 59 a$ & $916 \pm 15 c$ & $7.5 \pm 0.3 d$ & $17.5 \pm 1.7 \mathrm{c}$ \\
\hline \multirow[t]{2}{*}{ Tomato 1} & F1W & $148 \pm 12 b$ & $1989 \pm 63 a$ & $58.5 \pm 1.9 a$ & $29.1 \pm 3.2 \mathrm{a}$ \\
\hline & F1CK & $249 \pm 17 \mathrm{a}$ & $2014 \pm 173 a$ & $35.1 \pm 3.0 \mathrm{~b}$ & $14.0 \pm 1.3 \mathrm{~b}$ \\
\hline \multirow[t]{3}{*}{ Tomato 2} & F2W & $217 \pm 11 c$ & $1962 \pm 72 \mathrm{a}$ & $41.7 \pm 2.3 \mathrm{a}$ & - \\
\hline & F2CK & $328 \pm 24 a$ & $1978 \pm 96 a$ & $25.0 \pm 1.7 \mathrm{c}$ & - \\
\hline & F2D & $266 \pm 18 b$ & $1889 \pm 139 a$ & $32.3 \pm 1.4 b$ & - \\
\hline
\end{tabular}

Note: Values within a column in the same experiment followed by the same letters are not significantly different $(p<0.05)$

compared to furrow and drip irrigations. The cucumber yield increased at first, but then decreased as the negative pressure of the water supply increased. The PCK yield was higher than the PW4 yield in the cucumber experiment. However, it was $14.4 \%, 40.9 \%$, and $16.9 \%$ less than PW1, PW2, and PW3, respectively. In addition, there was no significant yield difference between F1W and F1CK. In the tomato 2 experiment, irrigation systems also had no influence on tomato yield. The NPI system, compared to traditional irrigation (e.g. PCK and F1CK), significantly increased WP in the cucumber and tomato experiments, but NUE decreased as the negative pressure of the water supply increased. The PW1, PW2, and PW3 treatments significantly increased NUE compared with the PCK treatment, whereas NUE in PCK was higher than PW4 in the cucumber experiment. The NUE in the F1W treatment was $107.1 \%$ higher than F1CK in the tomato experiment. Furthermore, negative pressure irrigation significantly increased the WP compared to furrow and drip irrigations in the tomato 2 experiment.

\subsection{Relationships among yield, WP, NUE, and soil properties}

The correlation coefficients among yield, WP, NUE, the averages for soil water and $\mathrm{NO}_{3}^{-}-\mathrm{N}$ contents, and the $\mathrm{CU}$ for soil water and $\mathrm{NO}_{3}^{-}-\mathrm{N}$ during the cucumber and tomato growth periods are shown in Table 4. The VSWC had a positive relationship with yield in the cucumber experiment, but no relationship with yield in the two tomato experiments. The VSWC and $\mathrm{NO}_{3}^{-}-\mathrm{N}$ content had a significant correlation with
NUE in the cucumber experiment, but no correlation with NUE in the tomato 1 experiment. The $\mathrm{CU}$ for soil water and $\mathrm{NO}_{3}^{-}-\mathrm{N}$ had positive correlations with WP in cucumber and tomato 1 experiments, and there was also a positive correlation between soil water content CU and NUE. We also found that the $\mathrm{CU}$ for soil water had a positive correlation with $\mathrm{WP}$ in the tomato 2 experiment. The $\mathrm{CU}$ for soil $\mathrm{NO}_{3}^{-}-\mathrm{N}$ had a positive correlation with NUE in the tomato 1 experiment, but no correlation in the cucumber experiment. The $\mathrm{CU}$ for soil water had a positive correlation with the $\mathrm{CU}$ for soil $\mathrm{NO}_{3}^{-}-\mathrm{N}$ in the three experiments.

\section{Discussion}

The soil water status method has been well documented and is widely used for irrigation scheduling (Kumar et al., 2019; Van Pelt and Wierenga, 2001). However, the efficient use of the method remains a challenge because traditional irrigation systems, such as furrow and sprinkler irrigation, are affected by the spatial and temporal variations in soil water content (Hendrickx et al., 1994; Zhao et al., 2012). In our study, NPI, a new subsurface irrigation technique, could solve the problem to improve WP and NUE by using its water supply characteristics, which is conducive to the promotion of NPI.

Efficient irrigation can provide suitable water supplies to vegetables based on water demand (Montesano et al., 2018). Therefore, establishing the relationship between the water supply characteristics of an irrigation system and vegetable water demand could help evaluate the 
Table 4

Correlative coefficients among yield, WP, NUE, and the averages of VSWC, SNC, $\mathrm{CU}_{\theta}$, and $\mathrm{CU}_{\mathrm{N}}$ during cucumber and tomato growth periods.

\begin{tabular}{|c|c|c|c|c|c|c|c|c|}
\hline Experiment & & Yield & WP & NUE & vSWC & SNC & $\mathrm{CU}_{\theta}$ & $\mathrm{CU}_{\mathrm{N}}$ \\
\hline \multirow[t]{7}{*}{ Cucumber } & Yield & 1 & $-0.10 \mathrm{~ns}$ & $0.71^{* *}$ & $0.54^{*}$ & $-0.29 \mathrm{~ns}$ & $0.26 \mathrm{~ns}$ & $0.12 \mathrm{~ns}$ \\
\hline & WP & & 1 & $0.20 \mathrm{~ns}$ & $-0.37 \mathrm{~ns}$ & $0.49 \mathrm{~ns}$ & $0.68^{* *}$ & $0.90^{\text {*** }}$ \\
\hline & NUE & & & 1 & $0.84^{* * *}$ & $-0.69^{* *}$ & $0.62 *$ & $0.29 \mathrm{~ns}$ \\
\hline & VSWC & & & & 1 & $-0.93^{* * *}$ & $0.35 \mathrm{~ns}$ & $-0.04 \mathrm{~ns}$ \\
\hline & SNC & & & & & 1 & $-0.22 \mathrm{~ns}$ & $0.21 \mathrm{~ns}$ \\
\hline & $\mathrm{CU}_{\theta}$ & & & & & & 1 & $0.85^{\text {*k* }}$ \\
\hline & $\mathrm{CU}_{\mathrm{N}}$ & & & & & & & 1 \\
\hline \multirow[t]{7}{*}{ Tomato 1} & Yield & 1 & $0.05 \mathrm{~ns}$ & $0.10 \mathrm{~ns}$ & $-0.52 \mathrm{~ns}$ & $-0.46 \mathrm{~ns}$ & $-0.21 \mathrm{~ns}$ & $-0.18 \mathrm{~ns}$ \\
\hline & WP & & 1 & $0.98^{* * *}$ & $0.28 \mathrm{~ns}$ & $-0.41 \mathrm{~ns}$ & $0.92^{* * *}$ & $0.96^{* *}$ \\
\hline & NUE & & & 1 & $0.16 \mathrm{~ns}$ & $-0.54 \mathrm{~ns}$ & $0.89^{*}$ & $0.95^{* *}$ \\
\hline & vSWC & & & & 1 & $0.73 \mathrm{~ns}$ & $0.57 \mathrm{~ns}$ & $0.43 \mathrm{~ns}$ \\
\hline & SNC & & & & & 1 & $-0.14 \mathrm{~ns}$ & $-0.28 \mathrm{~ns}$ \\
\hline & $\mathrm{CU}_{\theta}$ & & & & & & 1 & $0.98^{* * *}$ \\
\hline & $\mathrm{CU}_{\mathrm{N}}$ & & & & & & & 1 \\
\hline \multirow[t]{6}{*}{ Tomato 2} & Yield & 1 & $0.04 \mathrm{~ns}$ & - & $-0.64 \mathrm{~ns}$ & $-0.45 \mathrm{~ns}$ & $0.01 \mathrm{~ns}$ & $-0.12 \mathrm{~ns}$ \\
\hline & WP & & 1 & - & $-0.52 \mathrm{~ns}$ & $-0.56 \mathrm{~ns}$ & $0.93^{* * *}$ & $0.97^{* k *}$ \\
\hline & vSWC & & & & 1 & $0.46 \mathrm{~ns}$ & $-0.47 \mathrm{~ns}$ & $-0.47 \mathrm{~ns}$ \\
\hline & SNC & & & & & 1 & $-0.49 \mathrm{~ns}$ & $0.44 \mathrm{~ns}$ \\
\hline & $\mathrm{CU}_{\theta}$ & & & & & & 1 & $0.91^{* * *}$ \\
\hline & $\mathrm{CU}_{\mathrm{N}}$ & & & & & & & 1 \\
\hline
\end{tabular}

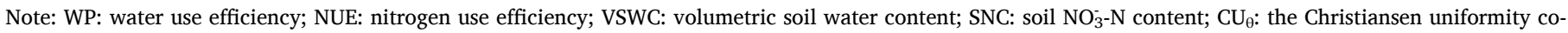
efficient of soil water; $\mathrm{CU}_{\mathrm{N}}$ : the Christiansen uniformity coefficient of soil $\mathrm{NO}_{3}^{-} \mathrm{N}$.; ns: not significant.

${ }_{* * *}^{*} p<0.001$;

*** $p<0.01$;

* $p<0.05$

irrigation technique. The cumulative water applications in the PW1N1 and PW2N1 treatments with nitrogen application were higher than PW1N0 and PW2N0 without nitrogen application. However, there was no significant difference in VSWC between the N1 and N0 treatments (Fig. 3). These results suggested that the NPI system could keep soil water content stable by automatically supplying irrigation water according to vegetable water demand and the NPI working principle. The NPI system will supply irrigation water as long as soil water is consumed because soil water consumption makes the pressure insider the emitter higher than soil matric potential. The system will automatically stop supplying irrigation when the soil matric potential is equal to the negative pressure insider the irrigation system. The negative pressure is controlled by a negative pressure generator (Fig. 1). Hence, NPI can provide different soil water contents by changing the negative pressure. In the cucumber experiment, the values of the negative pressure were $0 \mathrm{kPa},-5 \mathrm{kPa},-10 \mathrm{kPa}$, and $-15 \mathrm{kPa}$ that controlled the range of soil water content in $27.8-29.3 \%, 21.4-24.4 \%, 18.3-21.7 \%$, and 14.1-16.4\% during the cucumber growth periods, respectively (Fig. 3). Several researchers have also reported that soil water content was stable under each negative pressure of NPI during the plant growth period. For example, the VSWC under negative pressure of $-5 \mathrm{kPa}$ was $21.4-24.4 \%$ in our study (Fig. 3), 20.6-25.0\% in Li et al. (2019), and 9.7-11.7\% in Zhao et al. (2019).

Although soil water content at $-5 \mathrm{kPa}$ was stable in the above studies, their values were different. The reason for this is that soil water content under a specific negative pressure of NPI is mainly affected by soil texture (Wang et al., 2017) and emitter hydraulic conductivity that represents the ease with which water can pass through the emitter (Wang et al., 2019a, 2019b; Yang et al., 2020). Therefore, both factors should be considered when designing a NPI system. Furthermore, cucumber growth under the PW2 treatment was better than under PW1 in about 40-80 d because excessive soil water under PW1 treatment had a negative effect on cucumber growth (Li et al., 2017c). In addition, soil $\mathrm{NO}_{3}^{-}-\mathrm{N}$ content under PW2 was higher than under PW1 treatment (Fig. 6), which was beneficial for cucumber growth under PW2. Vegetables need more irrigation water when their growth improves because there is an increase in transpiration (Andrianasolo et al., 2016; Rodney, 1963). The NPI system can supply irrigation water based on the consumption of soil water. Although VSWC in PW1 was always higher than in PW2, the soil water that was absorbed by the cucumber in PW2 was higher than in PW1 between $40 \mathrm{~d}$ and $80 \mathrm{~d}$. Consequently, the cumulative water application value for the PW2 treatment was higher than PW1 between $40 \mathrm{~d}$ and $80 \mathrm{~d}$, whereas it was less than PW1 over 0-40 days (Fig. 3). Taken together, these results further confirmed the water supply characteristic of NPI that the water supply was automatically controlled by vegetable water demand.

The optimum soil water contents for different vegetables are varied (Contreras et al., 2017; Létourneau et al., 2015). For instance, the optimum soil matric potential for tomato, melon, and zucchini are -10 to $-30 \mathrm{kPa}$ (Wang et al., 2005), -35 to $-40 \mathrm{kPa}$ (Hanson et al., 2000), and $-25 \mathrm{kPa}$ (Contreras et al., 2017), respectively. The NPI system can obtain correspondent soil water content by controlling the negative pressure of water supply under a specified condition (e.g. soil texture). In our study, the VSWC decreased as the negative pressure of the NPI system increased and a significant exponential relationship was found (Fig. 4a and $b$ ). The result was consistent with previous research, which reported that soil water contents under pressures of $0,-5,-10$, and $-15 \mathrm{kPa}$ were $28.5 \%, 22.5 \%, 18.1 \%$, and $15.4 \%$, respectively (Zhao et al., 2017). The relationship between negative pressure and soil water content can be used to help formulate suitable negative pressure for a vegetable.

With the deepening of research on the optimum soil water content of vegetables, how to keep it stable needs to be urgently addressed. In our study, the VSWC of traditional irrigation treatments (PCK, F1CK, F2D) was $17.1-24.8 \%$ in the cucumber experiment, $16.7-23.9 \%$ in the tomato 1 experiment, and $21.8-27.3 \%$ in the tomato 2 experiment (Fig. 5), and we used the soil water content measurement method to control soil water content within 70-90\% of field capacity under PCK, F1CK, F2CK, and F2D treatments (Li et al., 2019). The specific value for soil water content mainly depends on irrigation frequency (Liu et al., 2019) and sampling time during the different growth stages (Badr and Abuarab, 2013). Furthermore, traditional irrigation, such as border and infiltration irrigation, needs to take into account the location of emitters, irrigation time, and soil water status (Létourneau et al., 2015) when attempting to keep soil water content stable. This requires relatively large manpower and material inputs. However, the NPI system can efficiently keep soil water content stable during the growth period by using its automatic water supply characteristics. The variation range for VSWC under the NPI system during the growth period was lower than 
for the PCK, F1CK, and F2D treatments (Fig. 5) and the Christiansen uniformity coefficient (CU) of the soil water under the NPI system in the topsoil was significantly higher than for the traditional irrigation treatments (Fig. 7). The main reason is that the NPI system automatically supplies water according to soil water consumption. In addition, the progress of supplying water is slow to infiltrate and it needs to take some time. Therefore, it is reasonable that the range of soil water content is floating, which is affected by temperature in the greenhouse ( $\mathrm{Li}$ et al., 2019), crop growth stage (Li et al., 2020), and emitter hydraulic conductivity (Wang et al., 2019a, 2019b). It is possible that the NPI system may not supply enough irrigation water in time, which means that the hysteresis effect of the water supply should be considered when attempting to grow water-intensive vegetables using the NPI system. Furthermore, although small sample sizes ( 4 and 5 samples) have been adopted in some previous studies when using the formula of CU (Kang et al., 2000; Zhao et al., 2012), the stability and credibility of the data cannot be ensured. In our study, only three samples were adopted to calculate CU, which could increase variability. However, it is true using $\mathrm{CU}$ to assess soil water and nitrogen distribution uniformities from the mathematical point of view (Kang et al., 2000). In addition, we conducted three experiments and measured $\mathrm{CU}$ four times during the vegetable growth period and found the result that the NPI system improved the distribution uniformity of soil water and $\mathrm{NO}_{3}^{-}-\mathrm{N}$ (Fig. 7). The result was consistent under different growth periods and experiments, which can reduce variability and increase credibility. We also believe that it is necessary to increase the sample size to further reduce the variability in future research.

Another advantage of the NPI system is that the system can continuously provide nitrogen fertilizer to the crops as the irrigation water is redistributed, which could improve the distribution uniformity of soil $\mathrm{NO}_{3}^{-}-\mathrm{N}$. In our study, the average $\mathrm{CU}$ for soil $\mathrm{NO}_{3}^{-}-\mathrm{N}$ under the NPI system was higher than for the CK treatment (Fig. 7). Furthermore, the fertilizer under the CK treatment was supplied over a shorter time compared with the NPI treatment. This result is consistent with a previous study, which found that continuous irrigation with fertilization could increase the distribution uniformity of soil $\mathrm{NO}_{3}^{-}-\mathrm{N}$ when a subsurface irrigation system was used (Phogat et al., 2013). The most likely reason for this is that soil $\mathrm{NO}_{3}^{-}-\mathrm{N}$ can transport in the soil with irrigation water (Barber, 1995). It has also been reported that the $\mathrm{CU}$ for soil $\mathrm{NO}_{3}^{-}-\mathrm{N}$ had a significant correlation with $\mathrm{CU}$ of soil water in the three experiments (Table 4). Furthermore, soil $\mathrm{NO}_{3}^{-}-\mathrm{N}$ content can influence root hydraulic properties (Gorska et al., 2008), which leads to greater soil water absorption in nitrate-rich areas (Zhou et al., 2018; Zotarelli et al., 2009a, 2009b). Therefore, it is necessary to consider the reciprocal impact between irrigation water and nitrogen fertilizer in the future to better understand the effect of the NPI system on vegetable growth. Although the distributions of soil water and $\mathrm{NO}_{3}^{-}-\mathrm{N}$ in vertical direction have been shown in this study, the spatial distribution is more helpful to reveal the effect of irrigation systems on crop growth (Li et al., 2005; Zhou et al., 2018). The spatial distribution of soil water content was also shown in our previous study (Wang et al., 2019a, 2019b). However, there is a lack of research on the effect of the spatial distribution of soil water and $\mathrm{NO}_{3}^{-}-\mathrm{N}$ on crop growth in our studies, especially the horizontal distribution, and further research is needed to address this topic.

The primary task of irrigation is to promote vegetable growth, especially in terms of yield, WP, and NUE (Mon et al., 2016; Montesano et al., 2018). Some studies have shown that the NPI system could increase yield and WP (Gao et al., 2019; Yang et al., 2020). In the cucumber experiment, the NPI system increased yield under appropriate pressure $(-10-0 \mathrm{kPa})$, but it decreased yield at $-15 \mathrm{kPa}$ (Table 3) compared with conventional treatment (PCK). This was due to the creation of serious water stress conditions. There was no significant difference in yield among the NPI, furrow irrigation, and drip irrigation in the two tomato experiments. However, the NPI system could reduce fertilizer and irrigation water inputs under the same yield requirement conditions. Li et al. (2019) also found that there were no significant differences in cucumber and tomato yields between the NPI system and drip irrigation.

The $\mathrm{CU}$ for soil water and $\mathrm{NO}_{3}^{-}-\mathrm{N}$ had no relationship with yield in the three experiments, but it had a positive relationship with WP and NUE at appropriate VSWC (Table 4). This is consistent with a previous result that showed there is no relationship between maize yield and the distribution uniformities for soil water and $\mathrm{NO}_{3}^{-}-\mathrm{N}$ under drip irrigation system because there was no water and nitrogen stress (Zhou et al., 2018). In the cucumber experiment, the $\mathrm{CU}$ for soil $\mathrm{NO}_{3}^{-} \mathrm{N}$ had no relationship with NUE because of the serious water stress at $-15 \mathrm{kPa}$, but there was a positive relationship between the soil $\mathrm{NO}_{3}^{-}-\mathrm{N}$ distribution and NUE at $-10-0 \mathrm{kPa}$. These results suggested that the NPI system could increase the $\mathrm{CU}$ of soil water and $\mathrm{NO}_{3}^{-}-\mathrm{N}$, and promote WP and NUE under appropriate water supply pressures. Some studies have also shown that increasing the $\mathrm{CU}$ of soil $\mathrm{NO}_{3}^{-}-\mathrm{N}$ improved the absorption and utilization of soil water and $\mathrm{NO}_{3}^{-} \mathrm{N}$ by vegetables (Barber, 1995; Zhou et al., 2018), and reduced water and $\mathrm{NO}_{3}^{-}-\mathrm{N}$ losses due to deep percolation (Zhao et al., 2012). In the two tomato experiments, the conventional treatment (furrow irrigation and drip irrigation) had higher soil water or $\mathrm{NO}_{3}^{-}-\mathrm{N}$ contents at $30 \mathrm{~cm}$ depth than the NPI system (Figs. 5 and 6). Therefore, the NPI system was able to further reduce the risk of water and $\mathrm{NO}_{3}^{-}-\mathrm{N}$ losses. Although our study showed that $\mathrm{CU}$ of soil water and $\mathrm{NO}_{3}^{-}-\mathrm{N}$ has a very important role in improving WP and NUE, few studies, to the best of our knowledge, have addressed this issue under the NPI system. As with other traditional irrigation methods, such as drip and sprinkling irrigation (Kang et al., 2000; Li and Liu, 2011), CU of soil water and $\mathrm{NO}_{3}^{-}-\mathrm{N}$ should be considered when designing an NPI system and because it strongly affects vegetable growth. The NPI, a new automatic subsurface irrigation technique, can directly supply irrigation water and fertilizer to the root zone and reduce evaporation, which increases WP and NUE in a similar way to other subsurface irrigation (Badr and Abuarab, 2013; Li et al., 2019). Furthermore, vegetables need different optimum soil water content at different growth stages (Kumar et al., 2019; Li et al., 2020) and the NPI system can accurately adjust soil water content according to vegetable water demand by changing the water supply pressure of the system. Hence, the NPI has a greater potential to promote vegetable growth in the future by supplying water according to vegetable water demand and through improvements to the soil water and nitrogen distribution uniformities.

\section{Conclusions}

The NPI system is an efficient irrigation technique that can promote vegetable yields, WP, and NUE under appropriate water supply pressures. This is because it has superior water supply characteristics and also can improve the soil water and $\mathrm{NO}_{3}^{-}-\mathrm{N}$ distribution uniformities. The $-5 \mathrm{kPa}$ treatment yield was highest in the cucumber experiment, and the $-5 \mathrm{kPa}$ treatment also produced higher WP and NUE than the CK treatment in cucumber and tomato experiments. The NPI system can automatically supply irrigation water according to the consumption of soil water and then keep soil water content stable during the vegetable growth period. The NPI system also increased the CU of soil water and $\mathrm{NO}_{3}^{-}-\mathrm{N}$ under appropriate water supply pressure conditions and improved WP and NUE. Therefore, the $\mathrm{CU}$ of soil water and $\mathrm{NO}_{3}^{-} \mathrm{N}$ should be considered when designing an NPI system because it strongly affects vegetable growth. Two issues have to be addressed if the abilities of the NPI system to promote vegetable growth are to be further improved. These are optimizing water supply pressures for a vegetable at its different growth stages and investigating the reciprocal impact between irrigation water and nitrogen fertilizer.

\section{Declaration of Competing Interest}

The authors declare that they have no known competing financial interests or personal relationships that could have appeared to influence the work reported in this paper. 


\section{Acknowledgments}

This research was supported by the National Key Research and Development Program of China (2018YFE0112300), National Key Research Development Program of China (2018YFD0200408), Science and Technology Project (2015BAD22B03). We wish to thank the editors and reviewers for their constructive comments.

\section{References}

Andrianasolo, F.N., Casadebaig, P., Langlade, N., Debaeke, P., Maury, P., 2016. Effects of plant growth stage and leaf aging on the response of transpiration and photosynthesis to water deficit in sunflower. Funct. Plant Biol. 43, 797-805. https:// doi.org/10.1071/FP15235.

Badr, M.A., Abou-Hussein, S.D., El-Tohamy, W.A., 2016. Tomato yield, nitrogen uptake and water use efficiency as affected by planting geometry and level of nitrogen in an arid region. Agric. Water Manag. 169, 90-97. https://doi.org/10.1016/j. agwat.2016.02.012.

Badr, A.E., Abuarab, M.E., 2013. Soil moisture distribution patterns under surface and subsurface drip irrigation systems in sandy soil using neutron scattering technique. Irrig. Sci. 31, 317-332. https://doi.org/10.1007/s00271-011-0306-0.

Barber, S.A., 1995. Soil Nutrient Bioavailability: A Mechanistic Approach. John Wiley \& Sons.

Christiansen, J.E., 1942. Irrigation by Sprinkling. University of California, Berkeley.

Contreras, J.I., Alonso, F., Cánovas, G., Baeza, R., 2017. Irrigation management of greenhouse zucchini with different soil matric potential level. Agronomic and environmental effects. Agric. Water Manag. 183, 26-34. https://doi.org/10.1016/j. agwat.2016.09.025.

Davis, S.L., Dukes, M.D., 2010. Irrigation scheduling performance by evapotranspirationbased controllers. Agric. Water Manag. 98, 19-28. https://doi.org/10.1016/j. agwat.2010.07.006.

Domínguez-Niño, J.M., Oliver-Manera, J., Girona, J., Casadesús, J., 2020. Differential irrigation scheduling by an automated algorithm of water balance tuned by capacitance-type soil moisture sensors. Agric. Water Manag. 228, 105880 https:// doi.org/10.1016/j.agwat.2019.105880.

Fernández, J.E., Alcon, F., Diaz-Espejo, A., Hernandez-Santana, V., Cuevas, M.V., 2020. Water use indicators and economic analysis for on-farm irrigation decision: a case study of a super high density olive tree orchard. Agric. Water Manag. 237, 106074 https://doi.org/10.1016/j.agwat.2020.106074.

Flörke, M., Schneider, C., McDonald, R.I., 2018. Water competition between cities and agriculture driven by climate change and urban growth. Nat. Sustain. 1, 51-58. https://doi.org/10.1038/s41893-017-0006-8.

Gan, Y., Siddique, K.H.M., Turner, N.C., Li, X.-G., Niu, J.-Y., Yang, C., Liu, L., Chai, Q., 2013. Ridge-furrow mulching systems - an innovative technique for boosting crop productivity in semiarid rain-fed environments. Adv. Agron. 118, 429-476. https:// doi.org/10.1016/B978-0-12-405942-9.00007-4.

Gao, X., Zhang, S., Zhao, X., Long, H., 2019. Evaluation of potassium application on tomato performance and rhizosphere bacterial communities under negative pressure irrigation of greenhouse-grown. J. Plant Nutr. 43, 317-326. https://doi.org/ 10.1080/01904167.2019.1683862.

Gorska, A., Ye, Q., Holbrook, N.M., Zwieniecki, M.A., 2008. Nitrate control of root hydraulic properties in plants: translating local information to whole plant response. Plant Physiol. 148, 1159-1167. https://doi.org/10.1104/pp.108.122499.

Guan, H., Li, J., Li, Y., 2013. Effects of drip system uniformity and irrigation amount on cotton yield and quality under arid conditions. Agric. Water Manag. 124, 37-51. https://doi.org/10.1016/j.agwat.2013.03.020.

Hanson, B.R., Orloff, S., Peters, D., 2000. Monitorina soil moisture hebs refine irriaation manaaement. Calif. Agric. 54, 38-42.

Hendrickx, J.M.H., Nieber, J.L., Siccama, P.D., 1994. Effect of tensiometer cup size on field soil water tension variability. Soil Sci. Soc. Am. J. 58, 309-315 https://doi.org/ 10.2136/sssaj1994.03615995005800020007x.

Henriques, C., Holman, I.P., Audsley, E., Pearn, K., 2008. An interactive multi-scale integrated assessment of future regional water availability for agricultural irrigation in East Anglia and North West England. Clim. Change 90, 89-111. https://doi.org/ 10.1007/s10584-008-9459-0.

Isidoro, D., Grattan, S.R., 2011. Predicting soil salinity in response to different irrigation practices, soil types and rainfall scenarios. Irrig. Sci. 29, 197-211. https://doi.org/ 10.1007/s00271-010-0223-7.

Jones, H.G., 2004. Irrigation scheduling: advantages and pitfalls of plant-based methods. J. Exp. Bot. 55, 2427-2436. https://doi.org/10.1093/jxb/erh213.

Kang, S.Z., Liang, Z.S., Hu, X.T., Pan, Y.H., Shi, P.Z., Zhang, J., 2000. Soil water distribution, uniformity and water-use efficiency under alternate furrow irrigation in arid areas. Irrig. Sci. 19, 181-190. https://doi.org/10.1007/s002710000019.

Kijne, J., Barker, R., 2003. Water Productivity in Agriculture: Limits and Opportunities for Improvement, Water Productivity in Agriculture: Limits and Opportunities for Improvement. CABI, Wallingford. https://doi.org/10.1079/9780851996691.0000.

Knipper, K.R., Kustas, W.P., Anderson, M.C., Alfieri, J.G., Prueger, J.H., Hain, C.R., Gao, F., Yang, Y., McKee, L.G., Nieto, H., Hipps, L.E., Alsina, M.M., Sanchez, L., 2019. Evapotranspiration estimates derived using thermal-based satellite remote sensing and data fusion for irrigation management in California vineyards. Irrig. Sci. 37, 431-449. https://doi.org/10.1007/s00271-018-0591-y.

Kumar, M., Kumar, N., Singh, K.P., Kumar, P., Srinivas, K., Srivastva, A.K., 2009. Integrating water harvesting and gravity-fed micro-irrigation system for efficient water management in terraced land for growing vegetables. Biosyst. Eng. 102, 106-113. https://doi.org/10.1016/j.biosystemseng.2008.09.026.

Kumar, S., Narjary, B., Kumar, K., Jat, H.S., Kamra, S.K., Yadav, R.K., 2019. Developing soil matric potential based irrigation strategies of direct seeded rice for improving yield and water productivity. Agric. Water Manag. 215, 8-15. https://doi.org/ 10.1016/j.agwat.2019.01.007.

Létourneau, G., Caron, J., Anderson, L., Cormier, J., 2015. Matric potential-based irrigation management of field-grown strawberry: effects on yield and water use efficiency. Agric. Water Manag. 161, 102-113. https://doi.org/10.1016/j. agwat.2015.07.005.

Liu, H., Li, H., Ning, H., Zhang, X., Li, S., Pang, J., Wang, G., Sun, J., 2019. Optimizing irrigation frequency and amount to balance yield, fruit quality and water use efficiency of greenhouse tomato. Agric. Water Manag. 226, 105787 https://doi.org/ 10.1016/j.agwat.2019.105787.

Li, J., Liu, Y., 2011. Water and nitrate distributions as affected by layered-textural soil and buried dripline depth under subsurface drip fertigation. Irrig. Sci. 29, 469-478. https://doi.org/10.1007/s00271-010-0255-z.

Li, J., Li, B., Rao, M., 2005. Spatial and temporal distributions of nitrogen and crop yield as affected by nonuniformity of sprinkler fertigation. Agric. Water Manag. 76, 160-180. https://doi.org/10.1016/j.agwat.2005.01.017.

Li, Y., Wang, L., Xue, X., Guo, W., Xu, F., Li, Youli, Sun, W., Chen, F., 2017b. Comparison of drip fertigation and negative pressure fertigation on soil water dynamics and water use efficiency of greenhouse tomato grown in the North China Plain. Agric. Water Manag. 184, 1-8. https://doi.org/10.1016/j.agwat.2016.12.018.

Li, S., Wu, X., Gao, L., Long, H., Li, J., Wang, B., Dang, J., Pei, X., 2017. Response of photosynthetic characteristics and water use efficiency of cucumber to soil water content. Sci. Agric. Sin. 50, 2993-3005. https://doi.org/10.3864/j.issn.05781752.2017.15.013.

Li, S., Wu, X., Liang, G., Gao, L., Wang, B., Lu, J., Abdelrhman, A.A., Song, X., Zhang, M., Zheng, F., Degré, A., 2020. Is least limiting water range a useful indicator of the impact of tillage management on maize yield? Soil Tillage Res. 199, 104602 https:// doi.org/10.1016/j.still.2020.104602.

Li, Y., Xue, X., Guo, W., Wang, L., Duan, M., Chen, H., Chen, F., 2019. Soil moisture and nitrate-nitrogen dynamics and economic yield in the greenhouse cultivation of tomato and cucumber under negative pressure irrigation in the North China Plain. Sci. Rep. 9, 1-9. https://doi.org/10.1038/s41598-019-38695-4.

Li, Y., Xue, X., Zhao, Q., Guo, W., Sun, W., Chen, X., 2017a. Automatic measurement of greenhouse tomato evapotranspiration based on negative pressure irrigation system. Trans. Chin. Soc. Agric. Eng. 33, 137-144. https://doi.org/10.11975/j.issn.10026819.2017.10.018.

Lopes, A.R., Boas, M.A.V., Pazuch, F.A., Corte, L.D., Ostroski, D.A., Remor, M.B., Mohr, F. B.M., Dotto, M., Zanella, A.P., Carvalho, A.F.G., Freddo, A.R., Bertoldo, I.C., Pirola, K., Giarola, C.M., 2019. Statistical quality control in uniformity of drip irrigation with different slopes. J. Agric. Sci. 11, 195. https://doi.org/10.5539/jas. v11n16p195.

Moniruzzaman, S.M., Fukuhara, T., Terasaki, H., 2011. Experimental study on water balance in a negative pressure difference irrigation system. J. Jpn. Soc. Civ. Eng. Ser. B1 Hydraul. Eng. 67, I_103-I_108. https://doi.org/10.2208/jscejhe.67.I_103.

Montesano, F.F., van Iersel, M.W., Boari, F., Cantore, V., D’Amato, G., Parente, A., 2018. Sensor-based irrigation management of soilless basil using a new smart irrigation system: effects of set-point on plant physiological responses and crop performance. Agric. Water Manag. 203, 20-29. https://doi.org/10.1016/j.agwat.2018.02.019.

Mon, J., Bronson, K.F., Hunsaker, D.J., Thorp, K.R., White, J.W., French, A.N., 2016. Interactive effects of nitrogen fertilization and irrigation on grain yield, canopy temperature, and nitrogen use efficiency in overhead sprinkler-irrigated durum wheat. F. Crop. Res. 191, 54-65. https://doi.org/10.1016/j.fcr.2016.02.011.

Nakhforoosh, A., Bodewein, T., Fiorani, F., Bodner, G., 2016. Identification of water use strategies at early growth stages in durum wheat from shoot phenotyping and physiological measurements. Front. Plant Sci. 7, 1-13. https://doi.org/10.3389/ fpls.2016.01155.

Van Pelt, R.S., Wierenga, P.J., 2001. Temporal stability of spatially measured soil matric potential probability density function. Soil Sci. Soc. Am. J. 65, 668-677. https://doi. org/10.2136/sssaj2001.653668x.

Phogat, V., Skewes, M.A., Cox, J.W., Alam, J., Grigson, G., Šimůnek, J., 2013. Evaluation of water movement and nitrate dynamics in a lysimeter planted with an orange tree. Agric. Water Manag. 127, 74-84. https://doi.org/10.1016/j.agwat.2013.05.017.

Quemada, M., Gabriel, J.L., 2016. Approaches for increasing nitrogen and water use efficiency simultaneously. Glob. Food Secur. 9, 29-35. https://doi.org/10.1016/j. gfs. 2016.05.004.

Rallo, G., González-Altozano, P., Manzano-Juárez, J., Provenzano, G., 2017. Using field measurements and FAO-56 model to assess the eco-physiological response of citrus orchards under regulated deficit irrigation. Agric. Water Manag. 180, 136-147. https://doi.org/10.1016/J.AGWAT.2016.11.011.

Rodney, A., 1963. Relationships between plant growth and transpiration. Hilgardia 34 (13), 559-584.

Rost, S., Gerten, D., Bondeau, A., Lucht, W., Rohwer, J., Schaphoff, S., 2008. Agricultural green and blue water consumption and its influence on the global water system. Water Resour. Res. 44, 1-17. https://doi.org/10.1029/2007WR006331.

Simonne, E., Studstill, D., Hochmuth, B., Olczyk, T., Dukes, M., Munoz-, R., Li, Y., 2014. Drip irrigation: the BMP era-an integrated approach to water and fertilizer management for vegetables grown with plasticulture. EDIS 1-14.

Thompson, R.B., Martínez-Gaitan, C., Gallardo, M., Giménez, C., Fernández, M.D., 2007. Identification of irrigation and $\mathrm{N}$ management practices that contribute to nitrate leaching loss from an intensive vegetable production system by use of a comprehensive survey. Agric. Water Manag. 89, 261-274. https://doi.org/10.1016/ j.agwat.2007.01.013. 
Tuccio, L., Lo Piccolo, E., Battelli, R., Matteoli, S., Massai, R., Scalabrelli, G., Remorini, D., 2019. Physiological indicators to assess water status in potted grapevine (Vitis vinifera L.). Sci. Hortic. 255, 8-13. https://doi.org/10.1016/j. scienta.2019.05.017.

Wang, J., Huang, Y., Long, H., Hou, S., Xing, A., Sun, Z., 2017. Simulations of water movement and solute transport through different soil texture configurations under negative-pressure irrigation. Hydrol. Process. 31, 2599-2612. https://doi.org/ 10.1002/hyp.11209.

Wang, Q., Klassen, W., Li, Y., Codallo, M., Abdul-Baki, A.A., 2005. Influence of cover crops and irrigation rates on tomato yields and quality in a subtropical region. HortScience 40, 2125-2131. https://doi.org/10.21273/hortsci.40.7.2125.

Wang, H., Li, J., Cheng, M., Zhang, F., Wang, X., Fan, J., Wu, L., Fang, D., Zou, H., Xiang, Y., 2019a. Optimal drip fertigation management improves yield, quality, water and nitrogen use efficiency of greenhouse cucumber. Sci. Hortic. 243, 357-366. https://doi.org/10.1016/j.scienta.2018.08.050.

Wang, J., Long, H., Huang, Y., Wang, X., Cai, B., Liu, W., 2019b. Effects of different irrigation management parameters on cumulative water supply under negative pressure irrigation. Agric. Water Manag. 224, 105743 https://doi.org/10.1016/j. agwat.2019.105743.

Wang, L., Xue, C., Pan, X., Chen, F., Liu, Y., 2018. Application of controlled-release urea enhances grain yield and nitrogen use efficiency in irrigated rice in the yangtze river basin, China. Front. Plant Sci. 9, 1-13. https://doi.org/10.3389/fpls.2018.00999.

Yang, P., Bian, Y., Long, H., Drohan, P.J., 2020. Comparison of emitters of ceramic tube and polyvinyl formal under negative pressure irrigation on soil water use efficiency and nutrient uptake of crown daisy. Agric. Water Manag. 228, 105830 https://doi. org/10.1016/j.agwat.2019.105830.
Yang, X., Liu, J., Xu, J., Duan, S., Wang, Q., Li, G., Jin, L., 2019. Transcriptome profiling reveals effects of drought stress on gene expression in diploid potato genotype P3198. Int. J. Mol. Sci. 20, 1-18. https://doi.org/10.3390/ijms20040852.

Zhao, X., Gao, X., Zhang, S., Long, H., 2019. Improving the growth of rapeseed (Brassica chinensis L.) and the composition of rhizosphere bacterial communities through negative pressure irrigation. Water Air Soil Pollut. 230. https://doi.org/10.1007/ s11270-018-4061-1.

Zhao, W., Li, J., Li, Y., Yin, J., 2012. Effects of drip system uniformity on yield and quality of Chinese cabbage heads. Agric. Water Manag. 110, 118-128. https://doi. org/10.1016/j.agwat.2012.04.007.

Zhao, X., Song, Y., Yue, X., Zhang, S., Wu, X., Long, H., 2017. Effect of different potassium levels on the growth of bok choy under negative pressure. Sci. Agric. Sin. 50, 689-697. https://doi.org/10.3864/j.issn.0578-1752.2010.02.014.

Zhou, L., He, J., Qi, Z., Dyck, M., Zou, Y., Zhang, T., Feng, H., 2018. Effects of lateral spacing for drip irrigation and mulching on the distributions of soil water and nitrate, maize yield, and water use efficiency. Agric. Water Manag. 199, 190-200. https://doi.org/10.1016/j.agwat.2017.12.028.

Zotarelli, L., Dukes, M.D., Scholberg, J.M.S., Muñoz-Carpena, R., Icerman, J., 2009a. Tomato nitrogen accumulation and fertilizer use efficiency on a sandy soil, as affected by nitrogen rate and irrigation scheduling. Agric. Water Manag. 96, 1247-1258. https://doi.org/10.1016/j.agwat.2009.03.019.

Zotarelli, L., Scholberg, J.M., Dukes, M.D., Muñoz-Carpena, R., Icerman, J., 2009b. Tomato yield, biomass accumulation, root distribution and irrigation water use efficiency on a sandy soil, as affected by nitrogen rate and irrigation scheduling. Agric. Water Manag. 96, 23-34. https://doi.org/10.1016/j.agwat.2008.06.007. 